\title{
Article
}

\section{Patellar taping for patellofemoral pain syndrome in adults}

Callaghan, Michael J and Selfe, James

Available at https://clok.uclan.ac.uk/7477/

Callaghan, Michael J and Selfe, James (2012) Patellar taping for patellofemoral pain syndrome in adults. The Cochrane Library, 2012 (4). pp. 1-41. ISSN 1469$493 x$

It is advisable to refer to the publisher's version if you intend to cite from the work. http://dx.doi.org/10.1002/14651858.CD006717.pub2

For more information about UCLan's research in this area go to

http://www.uclan.ac.uk/researchgroups/ and search for < name of research Group>.

For information about Research generally at UCLan please go to http://www.uclan.ac.uk/research/

All outputs in CLoK are protected by Intellectual Property Rights law, including Copyright law. Copyright, IPR and Moral Rights for the works on this site are retained by the individual authors and/or other copyright owners. Terms and conditions for use of this material are defined in the policies page.

\section{CLoK}

Central Lancashire online Knowledge www.clok.uclan.ac.uk

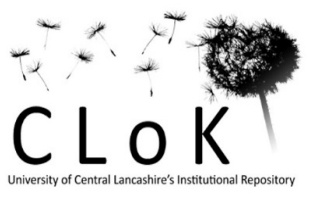




\title{
Patellar taping for patellofemoral pain syndrome in adults (Review)
}

\author{
Callaghan MJ, Selfe J
}

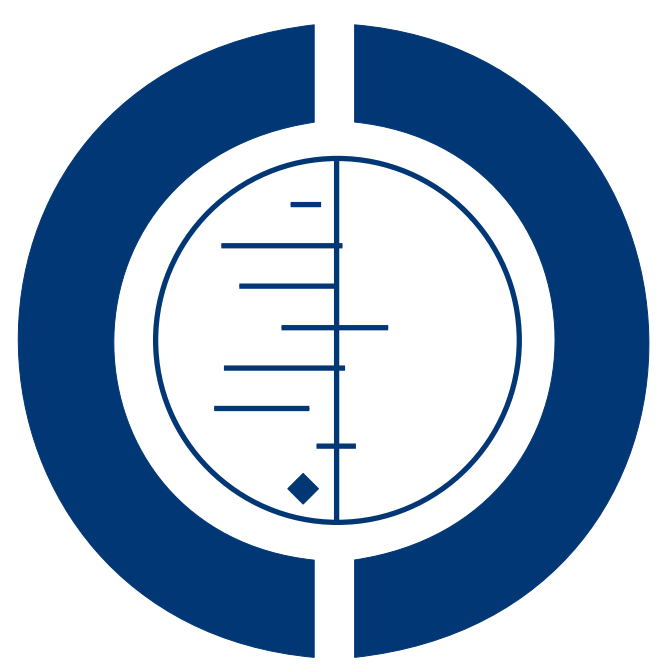

THE COCHRANE
COLLABORATION $^{\circledR}$

This is a reprint of a Cochrane review, prepared and maintained by The Cochrane Collaboration and published in The Cochrane Library 2012, Issue 4

http://www.thecochranelibrary.com

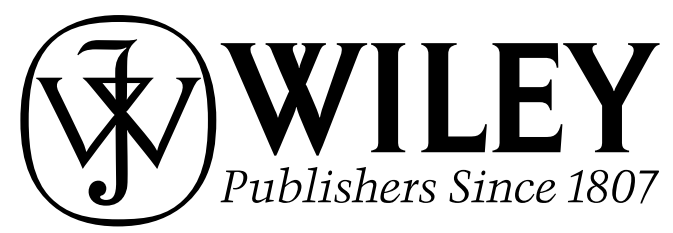

Patellar taping for patellofemoral pain syndrome in adults (Review)

Copyright $\odot 2012$ The Cochrane Collaboration. Published by John Wiley \& Sons, Ltd. 
TABLE OF CONTENTS

HEADER

ABSTRACT

PLAIN LANGUAGE SUMMARY

BACKGROUND

OBJECTIVES

METHODS

RESULTS

Figure 1.

Figure 2.

DISCUSSION

AUTHORS' CONCLUSIONS

ACKNOWLEDGEMENTS

REFERENCES

CHARACTERISTICS OF STUDIES

DATA AND ANALYSES

Analysis 1.1. Comparison 1 Patellar taping versus no or placebo taping, Outcome 1 Pain: VAS (0: no pain to 10: worst pain) at end of treatment.

Analysis 1.2. Comparison 1 Patellar taping versus no or placebo taping, Outcome 2 Pain: VAS (0: no pain to 10: worst pain) at end of treatment (no 'acute' cases).

Analysis 1.3. Comparison 1 Patellar taping versus no or placebo taping, Outcome 3 Pain: VAS (0: no pain to 10: worst pain) at 12 months.

Analysis 1.4. Comparison 1 Patellar taping versus no or placebo taping, Outcome 4 Functional index questionnaire (FIQ) score $(16=$ no problems $)$ at end of treatment.

Analysis 1.5. Comparison 1 Patellar taping versus no or placebo taping, Outcome 5 Cincinnati knee activity score $(100=$ full activity) at end of treatment.

Analysis 1.6. Comparison 1 Patellar taping versus no or placebo taping, Outcome 6 WOMAC score (0: no problems to 96: extreme problems) at end of treatment.

Analysis 1.7. Comparison 1 Patellar taping versus no or placebo taping, Outcome 7 WOMAC score (0: no problems to 96 : extreme problems) at 12 months.

Analysis 1.8. Comparison 1 Patellar taping versus no or placebo taping, Outcome 8 Referred for further treatment (after 3 months).

Analysis 1.9. Comparison 1 Patellar taping versus no or placebo taping, Outcome 9 Further course of physiotherapy (after 3 months).

Patellar taping for patellofemoral pain syndrome in adults (Review) 


\title{
[Intervention Review]
}

\section{Patellar taping for patellofemoral pain syndrome in adults}

\author{
Michael J Callaghan ${ }^{1}$, James Selfe ${ }^{2}$ \\ ${ }^{1}$ Arthritis Research UK Epidemiology Group, University of Manchester, Manchester, UK. ${ }^{2}$ School of Sport, Tourism and The Outdoors, \\ University of Central Lancashire, Preston, UK \\ Contact address: Michael J Callaghan, Arthritis Research UK Epidemiology Group, University of Manchester, Oxford Road, Manch- \\ ester, M13 9PT, UK. michael.callaghan@manchester.ac.uk.
}

Editorial group: Cochrane Bone, Joint and Muscle Trauma Group.

Publication status and date: New, published in Issue 4, 2012.

Review content assessed as up-to-date: 20 November 2011.

Citation: Callaghan MJ, Selfe J. Patellar taping for patellofemoral pain syndrome in adults. Cochrane Database of Systematic Reviews 2012, Issue 4. Art. No.: CD006717. DOI: 10.1002/14651858.CD006717.pub2.

Copyright (C) 2012 The Cochrane Collaboration. Published by John Wiley \& Sons, Ltd.

\begin{abstract}
A B S T R A C T
Background

Patellofemoral pain syndrome refers to the clinical presentation of knee pain related to changes in the patellofemoral joint. Patellofemoral pain syndrome usually has a gradual onset of pain with none of the features associated with other knee diseases or trauma. It is often treated by physiotherapists, who use a variety of techniques including patellar taping. This involves the application of adhesive sports medical tape applied directly to the skin over the patella on the front of the knee. Patients often report an instantaneous improvement in pain and function after the tape is applied, but its longer term effects are uncertain.
\end{abstract}

\section{Objectives}

The objective was to assess the effects, primarily on pain and function, of patellar taping for treating patellofemoral pain syndrome in adults.

\section{Search methods}

We searched the Cochrane Bone, Joint and Muscle Trauma Group Specialised Register, the Cochrane Central Register of Controlled Trials, MEDLINE, CINAHL, EMBASE, PEDro, SPORTDiscus, AMED, reference lists of articles, trial registers and conference proceedings. All were searched to August 2011.

\section{Selection criteria}

Randomised controlled trials and quasi-randomised controlled trials testing the effects of patellar taping on clinically relevant outcomes, pain and function, in adults with patellofemoral pain syndrome. We excluded studies testing only the immediate effects of tape application.

\section{Data collection and analysis}

Both review authors independently performed study selection, data extraction and assessment of risk of bias. Trialists were contacted for more information. Data were pooled where possible.

Patellar taping for patellofemoral pain syndrome in adults (Review)

Copyright () 2012 The Cochrane Collaboration. Published by John Wiley \& Sons, Ltd. 


\section{Main results}

Five small heterogeneous randomised controlled trials, all at high risk of performance bias and most at risk of at least one other type of bias, were included. These involved approximately 200 participants with a diagnosis of patellofemoral pain syndrome. All compared taping versus control (no or placebo taping) and all included one or more co-interventions given to both taping and control group participants; this was prescribed exercise in four trials. The intensity and length of treatment was very varied: for example, length of treatment ranged from one week in one trial to three months in another. A meta-analysis of the visual analogue scale (VAS) pain data (scale 0 to 10: worst pain), measured in different ways, from four trials (data from 161 knees), found no statistically or clinically significant difference between taping and non taping in pain at the end of the treatment programmes (mean difference (MD) - 0.15 ; $95 \%$ confidence interval (CI) -1.15 to 0.85 ; random-effects model used given the significant heterogeneity $(\mathrm{P}<0.0001)$ ). Data for other outcomes measuring function and activities of daily living were from single trials only and gave contradictory results.

\section{Authors' conclusions}

The currently available evidence from trials reporting clinically relevant outcomes is low quality and insufficient to draw conclusions on the effects of taping, whether used on its own or as part of a treatment programme. Further research involving large, preferably multi-centre, good quality and well reported randomised controlled trials that measure clinically important outcomes and long-term results is warranted. Before this, consensus is required on the diagnosis of patellofemoral pain syndrome, the standardisation of outcome measurement and an acceptable approach for patellar taping.

\section{PLAIN LANGUAGE SUMMARY}

\section{Taping across the knee cap for adults with persistent pain at the front of the knee (patellofemoral pain)}

Pain at the front of the knee (also known as anterior knee pain or patellofemoral pain) is a common problem which particularly affects those who do some form of sport or exercise. Typically, it gets worse when going up and down stairs, squatting, kneeling and sitting with the knee bent. It is a distinct and separate condition from knee arthritis.

Such anterior knee pain is often treated by physiotherapists, who use a variety of techniques. One such technique is the use of a simple piece of adhesive tape across the knee cap to control the positioning of the knee-cap (patella) and potentially reduce the pain during movement.

The review found five trials, involving around 200 participants with this condition, which compared the clinical use of taping with no taping. All five studies differed from each other in terms of the type of participants (one trial involved army recruits), length and schedule of the treatment programme and assessment of outcome. In four trials, participants of both taping and no or placebo taping groups were prescribed exercises. In part because both the therapist and the patient knew whether they were getting taping, some caution was necessary in interpreting the study results. Pooled results from four trials (161 knees) for the level of pain at the end of the treatment programme (ranging for one week to three months) showed no difference between those given taping and those not. Data for other outcomes measuring function and activities of daily living were from single trials only and gave different results.

The review concluded that the currently available evidence from trials reporting clinically relevant outcomes is and low quality and insufficient to draw conclusions on the effects of taping. However, before further trials are conducted, some consensus is required to establish the typical patients, taping technique and the best way of measuring outcome.

B A C K G R O U N D

\section{Description of the condition}

Patellofemoral pain syndrome refers to the clinical presentation of knee pain related to changes in the patellofemoral joint. Patellofemoral pain syndrome usually has a gradual onset of pain with none of the features associated with other knee injuries or 
diseases. Authors in the United Kingdom (Anderson 2003), mainland Europe (Witvrouw 2003), Australia (McConnell 1996) and the USA (Brechter 2002) have stated that $25 \%$ of the adult population present with patellofemoral pain at some point, but have cited data from studies involving sporting or military cohorts. As a recent population estimate for adults aged between 19 to 50 years is just over 25 million in England alone (ONS 2007), these estimates may indicate that patellofemoral pain syndrome is a considerable health burden. However, the true prevalence and incidence of patellofemoral pain syndrome in the population as a whole remains unknown (Callaghan 2007).

Patellofemoral pain syndrome can cause functional limitations (Callaghan 1996; Callaghan 2004). The best way to manage the condition remains controversial and treatment failure rates are reported to be high (Brown 2000). Researchers have shown that patients may have higher than expected levels of disability (Clark 2000b) and psychological morbidity (Jensen 2005). A significant number may still experience symptoms many years after diagnosis (Nimon 1998) and there are concerns that the syndrome may predispose to osteoarthritis (Utting 2005). However, the possibility that anterior knee pain is a risk factor for incident patellofemoral osteoarthritis warrants further attention (Thomas 2010). The aetiology of patellofemoral pain syndrome is also unclear, with some studies suggesting that biomechanical abnormalities may be precipitated by occupation, sports or footwear (Cheung 2006). Higher body mass indices have been observed in patients with patellofemoral pain syndrome (Clark 2000b) and this apparent association cannot be ignored given the increasing prevalence of obesity in society.

\section{Anatomical considerations for this condition}

The patellofemoral joint is a complex joint arrangement between the back of the patella (knee-cap) and the reciprocally shaped distal end of the femur (thigh bone). The patella is a rounded bone embedded in the quadriceps tendon and is the largest of its kind (a sesamoid bone) in the body. Its joint surface has a large flat area on the outside, a smaller convex area on the inside, which in turn has a smaller area at its extreme, usually described as the 'odd facet' (Goodfellow 1976). The patellofemoral joint is a synovial joint and is the least stable joint in the lower limb; it has six degrees of freedom of motion and very large forces of multiple times the body weight are applied rapidly through a wide range of motion during everyday functional activities (Selfe 2010b). The primary role of the patella is to increase the efficiency and mechanical advantage of the large quadriceps muscles on the front of the thigh (Malek 1981). It also has a role in distributing the compressive forces at the joint by increasing the contact area between patella and thigh bone. The patella provides a fulcrum for the static and dynamic stabilisation supports (Malek 1981). The static stabilisers of the patella are a variety of ligaments, bursae (fluid sacs) and fascial tissue that keep the patella in its position in the centre of the knee. The dynamic stabilisers are muscle and tendons, the most important of which are the quadriceps muscles and, to a lesser extent, the hamstrings at the back of the thigh.

\section{Description of the intervention}

Patellar taping is an inexpensive technique readily and often used in the treatment of patients with patellofemoral pain syndrome. The technique involves the application of adhesive sports medical tape directly to the skin over the patella on the front of the knee. Usually, this tape is applied by physiotherapists during a treatment session but it can also be applied by patients at home and left on during waking hours. A variety of taping methods and techniques are in use. These include variations in the type of tape (elastic or rigid), the direction of pull of the tape (medial, lateral, inferior, superior, rotational, or no directional pull at all) and the number of layers of tape applied over the patella.

\section{How the intervention might work}

The dominant theory from both orthopaedic and physiotherapy perspectives is that most patellofemoral pain is the result of some form of patellar malalignment. But although it is purported to be present in the majority of patients with gradual, non-arthritic and non-traumatic patellar pain, the same cannot be said for adolescents who usually have patella problems related to growth and development (Grelsamer 1998). Physical correction of malalignment is just one of the reasons why patellar taping is thought to be beneficial for patellofemoral pain syndrome and there is an implication that the correction of static stability may restore normal patellar tracking by also improving dynamic stability. McConnell 1986 originally described patellar taping as part of a treatment programme for patellofemoral pain syndrome and theorised that this technique could alter patellar alignment, enhance contractions of the vastus medialis oblique (VMO) muscle, and hence decrease pain. Although these theories how a taping intervention might work were accepted for many years, subsequent studies have been contradictory regarding the ability of taping to realign patellar position (Crossley 2000) and to enhance VMO contractions (Cerny 1995b). Nevertheless, a number of studies have shown that patellar taping does decrease pain in patients with patellofemoral pain syndrome (for example, Powers 1997b), although the mechanism for this symptomatic improvement remains unknown (Callaghan 1997; Selfe 2004).

\section{Why it is important to do this review}

While the true health burden of patellofemoral pain syndrome is not known, it is common in young active adults and a source of long term disability (Clark 2000b; Nimon 1998). The best way to manage the condition is not known and treatment failures 
are frequent (Brown 2000). Patellar taping is commonly used in clinical practice for this condition either as a sole technique, or more commonly in conjunction with an exercise programme. We set out to systematically review the evidence for patellar taping for treating patellofemoral pain syndrome.

\section{O B J E C T I VES}

To assess the effects, primarily on pain and function, of patellar taping for treating patellofemoral pain syndrome in adults.

\section{METHODS}

\section{Criteria for considering studies for this review}

\section{Types of studies}

We included randomised controlled trials and quasi-randomised controlled trials (a method of allocating participants to a treatment that is not strictly random; i.e. by date of birth, hospital record number, or alternation) evaluating patellar taping for adults with patellofemoral pain syndrome.

\section{Types of participants}

Adults, aged 18 and above, diagnosed with patellofemoral pain syndrome. Patellofemoral pain syndrome could include other terms or synonyms associated with the condition (e.g. anterior knee pain, patella malalignment syndrome, retropatellar pain) as long as those studies had applied criteria to exclude other causes of pain not related to the patellofemoral joint. Trials that treated patients after a patella fracture, patella dislocation or subluxation or patients with a history of recurrent dislocation and subluxation were excluded. Also excluded were trials involving patients with concomitant neurological, rheumatological or cardiovascular problems.

\section{Types of interventions}

We included studies comparing any kind of patellar taping, thus where patients were randomly allocated to receive any kind of adhesive tape across the patella, versus placebo taping (i.e. tape placed across the surface of the patella without correction to patella alignment) or no taping. Patellar taping could be the only intervention or applied with other interventions, such as home exercises, as long as the same interventions were provided to the control group as well.
We excluded studies that compared patellar taping with another intervention (such as exercises) or that compared composite interventions, that included patellar taping, with no intervention or different interventions.

\section{Types of outcome measures}

We considered the following outcome measures:

1. Pain during activities or at rest

- Patient assessment scales such as (but not exclusively limited to) the visual analogue scale (VAS) and self-reported questionnaires subject and sensitive to patellofemoral pain syndrome such as the Kujala Patellofemoral Pain Score; the Functional Index Questionnaire; the Modified Functional Index Questionnaire; and other scoring systems related to the knee joint or patellofemoral pain syndrome.

\section{Function}

- Patient functional assessment scales such as (but not exclusively limited to) the visual analogue scale (VAS) and selfreported questionnaires subject and sensitive to patellofemoral pain syndrome such as the Kujala Patellofemoral Pain Score; the Functional Index Questionnaire; the Modified Functional Index Questionnaire; and other scoring systems related to the knee joint or patellofemoral pain syndrome.

\section{Activity levels}

- Patient activity assessment scales such as (but not exclusively limited to) the visual analogue scale (VAS) and selfreported questionnaires subject and sensitive to patellofemoral pain syndrome such as the Kujala Patellofemoral Pain Score; the Modified Functional Index Questionnaire (MFIQ); the Functional Index Questionnaire (FIQ); and other scoring systems related to the knee joint or patellofemoral pain syndrome.

\section{Quality of life}

- Patient quality of life assessment scales such (but not exclusively limited to) self-reported questionnaires subject and sensitive to patellofemoral pain syndrome such as the Kujala Patellofemoral Pain Score; the Functional Index Questionnaire; the Modified Functional Index Questionnaire, the Western Ontario and McMaster University Osteoarthritis Index (WOMAC); and the Medical Outcomes study short form 36 (SF-36).

\section{Timing of outcome assessment}

The time points considered are as follows.

1. Immediately after the completion of a treatment programme. 2. Preferably at least six months follow-up when taping is used as part of a treatment programme.

We did not consider trials where outcome measures such EMG (electromyogram) data, gait analysis, patellar position or alignment were studied without pain evaluation.

Patellar taping for patellofemoral pain syndrome in adults (Review) 


\section{Search methods for identification of studies}

\section{Electronic searches}

We searched the Cochrane Bone, Joint and Muscle Trauma Group Specialised Register (August 2011), the Cochrane Central Register of Controlled Trials (2011, Issue 5), MEDLINE (1950 to 20 August 2011), EMBASE (1980 to 20 August 2011), CINAHL (1982 to 20 August 2011), PEDro - The Physiotherapy Evidence Database (20 August 2011), SPORTDiscus (1830 to 20 August 2011), AMED (1985 to 20 August 2011). We also searched for theses via the following databases available through the University of Manchester and University of Central Lancashire libraries: the Thesis Canada Protocol; the Australian Digital Thesis Program; and ProQuest. For conference proceedings we searched the Chartered Society of Physiotherapy in-house library catalogue (20 August 2011). For ongoing trials we also searched using the metaRegister of Controlled Trials (mRCT) at Current Controlled Trials (20 August 2011). There were no language restrictions. In MEDLINE (OVID ONLINE), the search strategy was combined with the first two sections of the optimal MEDLINE search strategy for randomised controlled trials (Higgins 2005) (Appendix 1). Search strategies for the Cochrane Central Register of Controlled Trials, EMBASE, CINAHL, PEDro, SPORTDiscus and AMED can also be found in Appendix 1.

\section{Searching other resources}

We searched reference lists of articles and contacted experts in the field in order to identify unpublished trials.

\section{Data collection and analysis}

\section{Selection of studies}

Both authors (MJC and JS) independently reviewed the title, abstract and descriptors of each paper identified from the results of the literature searches with the aim of selecting trials for the main review. We then reviewed the full text of the trials that appeared to meet the criteria. Consensus was reached between the two authors without need for third party intervention.

\section{Data extraction and management}

Both authors (MJC and JS) independently extracted trial data using a double extraction process. Details from included studies were then entered into RevMan by MJC. We made several attempts to contact trialists for additional information on trial methodology and missing data.

\section{Assessment of risk of bias in included studies}

Both authors (MJC and JS) independently assessed the risk of bias of included studies using The Cochrane Collaboration's 'Risk of bias' tool (Higgins 2008). We assessed risk of selection bias (based on an assessment of random sequence generation and allocation concealment), performance bias (based on assessment of blinding of participants and therapists administrating the treatment), detection bias (based on assessment of assessor blinding), attrition bias (based on assessment of completeness of outcome data), and 'other bias'. For 'other bias', we assessed comparability of the treatment groups at baseline, the inclusion of other care programmes for the participants, and the monitoring treatment compliance during the trial. Disagreement was resolved by consensus without recourse to third party intervention. Neither author was blinded to the authorship of studies.

\section{Measures of treatment effect}

Where available, quantitative data were presented for the outcomes listed for each trial. Mean differences and 95\% confidence intervals were calculated for continuous data, and risk ratios and 95\% confidence intervals were calculated for dichotomous outcome measures.

\section{Unit of analysis issues}

We did not address the potential for unit of analysis issues in our protocol. However, while the inclusion of bilateral cases in some trials is a problem, it was irresolvable because of lack of data.

\section{Dealing with missing data}

We contacted trial authors for missing data. Where data were available, we conducted intention-to-treat analyses performed but otherwise used the data as presented. There were insufficient data to conduct sensitivity analyses to explore the effects of drop outs and exclusions.

\section{Assessment of heterogeneity}

Heterogeneity between comparable trials was evaluated visually and its presence tested using the chi-squared test with a $P$ value of $<0.1$ being statistically significant. Consistency between the studies was also calculated using the $\mathrm{I}^{2}$ test and larger values were considered as an indicator of substantial heterogeneity.

\section{Data synthesis}

For each study, the risk ratio (RR) and 95\% confidence intervals (CI) were calculated for dichotomous outcomes and mean differences and $95 \%$ confidence intervals for continuous outcomes. While we planned to use the standardised mean difference where 
it was necessary to combine the results from different scales, we made an exception for pain data that could be converted for presentation on a $10 \mathrm{~cm}$ visual analogue scale. When there was no heterogeneity, we pooled data using the fixed-effect model. If there was significant heterogeneity, we considered pooling data using the random-effects model.

\section{Subgroup analysis and investigation of heterogeneity}

Subgroup analyses were undertaken within RevMan for trials that included an exercise co-intervention and those that did not. We were unable to conduct our two other planned subgroup analyses to investigate gender (i.e. did females gain more benefit than males from taping?) and the population studied (i.e. trials that focused on the sporting population, the military population or the general adult population). We looked at the effect on the pain results from the exclusion of the only trial testing taping on people with acute patellofemoral pain.

\section{Sensitivity analysis}

There were insufficient data to perform our planned sensitivity analyses on various aspects of trial methodology such as concealment of allocation, inclusion and exclusion criteria and accounting for missing data. We looked at the effects of analysing the data with fixed-effect and random-effects models for pain.

\section{RES U L T S}

\section{Description of studies}

See: Characteristics of included studies; Characteristics of excluded studies; Characteristics of studies awaiting classification.

\section{Results of the search}

Two hundred and eighty references were retrieved, from which 45 potentially eligible studies were identified. Of these, five studies were included, 36 were excluded and one study (Miller 2010), which is only published as a conference abstract, is awaiting assessment. All of the fully reported potentially eligible studies were published in English language journals except for Nafstad 1996, which was in Norweigian, and Wijnen 1996, which was in Dutch. Upon translation, both these trials were excluded.

\section{Included studies}

Details of all the five individual trials (Clark 2000a; Kowall 1996; Mason 2011; Tunay 2003; Whittingham 2004) can be found in the Characteristics of included studies. A summary of these is presented below.

\section{Design}

All five studies were randomised parallel group trials. Three trials (Clark 2000a; Mason 2011; Tunay 2003) had four treatment groups, but two groups in each of Mason 2011 and Tunay 2003 were excluded because they tested interventions that were outside the scope of this review. Kowall 1996 had two groups and Whittingham 2004 had three groups, of which one was a placebo control.

\section{Sample sizes}

In total, there were approximately 200 participants with a total of 216 knees diagnosed with patellofemoral pain syndrome. All five trials were small. The sample sizes ranged from 25 participants in Kowall 1996 to 81 in Clark 2000a. However, the numbers of participants in individual groups ranged from 10 (Whittingham 2004) to 22 (Clark 2000a).

\section{Setting}

The trials were conducted in one of four countries: Australia (Mason 2011), Turkey (Tunay 2003), UK (Clark 2000a; Whittingham 2004) and USA (Kowall 1996). Two trials were in the military setting (Tunay 2003; Whittingham 2004).

\section{Participants}

All participants had a diagnosis of patellofemoral pain syndrome. The variety of the criteria used in the trials for this diagnosis is evident from inspection of the Characteristics of included studies. Tunay 2003 did not describe the gender mix of their participants, although the probable military connection indicates the possibility of a larger proportion of males. The percentages of male participants ranged from 32\% (Kowall 1996) to 80\% (Whittingham 2004). Whittingham 2004, which involved military recruits, had the youngest population (mean age 18.7 years) and Mason 2011, the oldest population (mean age 45 years). Notably, Mason 2011, which had a wider age range of 13 to 82 years, specifically did not exclude patients with arthritis of the patellofemoral joint. Cases were described as "acute" in Whittingham 2004. While some participants, such as in Mason 2011, were under 18 years of age, we anticipate these would have been few in number. The duration of symptoms was at least one month and generally much longer in the other four trials. The mean duration of symptoms was 2.5 years in Kowall 1996, 71 months in Mason 2011, and 1.8 years in Tunay 2003. In Clark 2000a, 74\% had symptoms for over 12 months. No details of previous treatment, if any, were provided in these four trials.

Patellar taping for patellofemoral pain syndrome in adults (Review) 


\section{Interventions}

Where available, details of the different methods (type and technique) for taping used in the five trials are presented in the Characteristics of included studies.

Clark 2000a had four treatment groups, and made two comparisons.

Two studies (Clark 2000a; Mason 2011) compared taping with no taping. All participants in these trials received education or advice. Four trials (Clark 2000a; Kowall 1996; Tunay 2003; Whittingham 2004) compared taping with exercises versus exercises without taping. As for the above comparison, all participants in Clark 2000a received education. In Tunay 2003, all participants had ice applied. Whittingham 2004 had two control groups, one of which had placebo taping. The intensity and length of treatment was very varied: for example, length of treatment ranged from one week in Mason 2011 to three months in Clark 2000a.

None of the trials reported on the prescription or use of analgesics. However, advice on pain controlling drugs was part of the education intervention provided in Clark 2000a.

\section{Outcomes}

Follow-up assessment was at the end of treatment in all five trials. Clark 2000a also followed up participants at 12 months.

All five trials recorded participants' pain levels using the visual analogue scale/score (VAS). The definitions of pain varied. Clark 2000a combined the results from two pain outcomes (one for climbing stairs and one for flat walking); Kowall 1996 measured pain during activities of daily living; Mason 2011 measured pain scores for four activities, including a self selected activity; Tunay 2003 did not provide details; and Whittingham 2004 reported average 24 hour pain and pain on stepping down.

Functional Index Questionnaire (FIQ) scores were reported by Whittingham 2004; Cincinnati knee activity score data were reported by Tunay 2003; WOMAC scores at end of treatment and 12 months by Clark 2000a. Clark 2000a also provided data on referral post-treatment and further physiotherapy, reported at 12 months.

\section{Excluded studies}

The reasons for excluding 36 studies are given in the Characteristics of excluded studies. Twenty-five studies were excluded because they only assessed the effect of patellar taping immediately post-application. Seven trials were excluded because they did not compare taping with no or placebo taping. The remaining four studies were excluded for a variety of other reasons.

\section{Risk of bias in included studies}

For more information about the risk of bias assessment, please see Figure 1 and Figure 2. 
Figure I. Risk of bias summary: review authors' judgements about each risk of bias item for each included study.

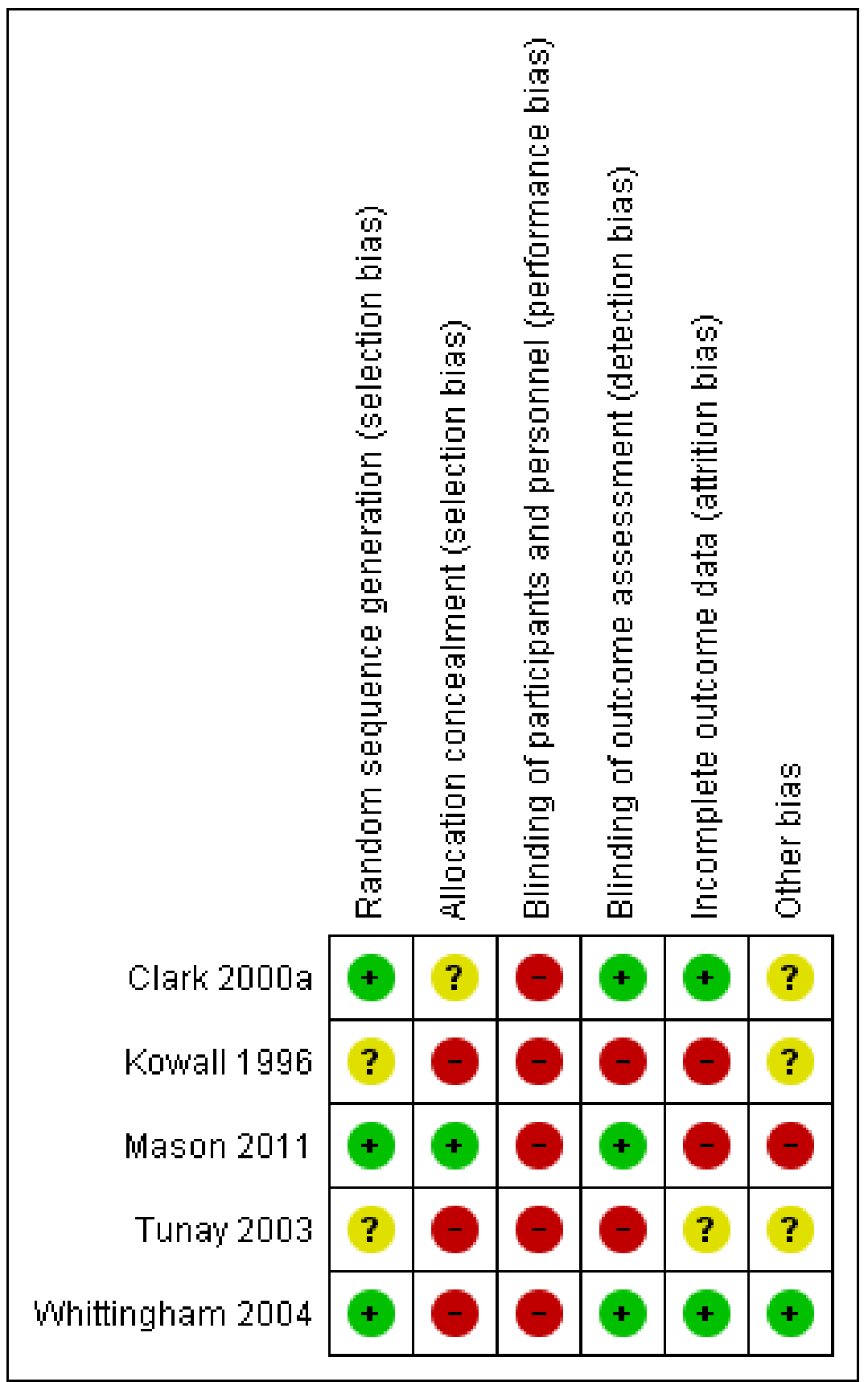

Patellar taping for patellofemoral pain syndrome in adults (Review)

Copyright (־ 2012 The Cochrane Collaboration. Published by John Wiley \& Sons, Ltd. 
Figure 2. Risk of bias graph: review authors' judgements about each risk of bias item presented as percentages across all included studies.

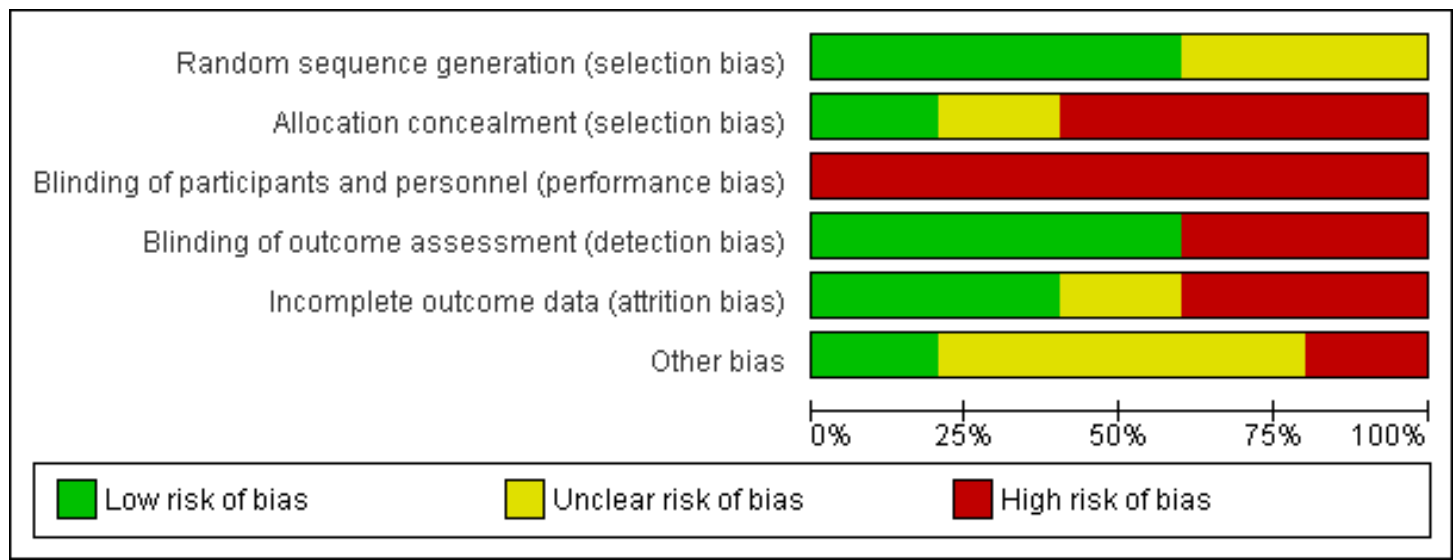

\section{Allocation}

The independent administration of pre-numbered sealed envelopes meant that Mason 2011 was considered at low risk of selection bias. There was insufficient information to determine whether allocation concealment was achieved in Clark 2000a. The other three trials were considered at high risk of selection bias, relating to lack of allocation concealment. This was retrospective in Kowall 1996, where patients consented after randomisation but no details were given as to whether any refused consent.

\section{Blinding}

A major risk of bias was that no studies were able to blind the therapists who were giving the treatment. This was a difficult area to control because by the very nature of the complex interventions used, it was generally not possible to blind the participants to treatment.

Three studies (Clark 2000a; Mason 2011; Whittingham 2004) were considered to have achieved assessor blinding and thus were at low risk of detection bias.

\section{Incomplete outcome data}

Two trials (Clark 2000a; Whittingham 2004) were judged at low risk of attrition bias. Two trials (Kowall 1996; Mason 2011) were judged at high risk of bias, in part relating to potential unit of analyses problems reflecting the inclusion of bilateral cases. Tunay 2003 was judged at unclear risk of attrition bias.

\section{Other potential sources of bias}

Assessment of other bias resulted in a judgement of 'unclear risk' in three trials (Clark 2000a; Kowall 1996; Tunay 2003) and low risk in Whittingham 2004. However, we considered Mason 2011 was at high risk of bias given the lack of information on baseline characteristics and potential imbalance in people with patellofemoral osteoarthritis.

\section{Effects of interventions}

The effects of patellar taping were assessed by the main outcome measures of pain, functional scores, activity levels and quality of life. The two comparisons (taping versus no taping, and taping plus exercise versus exercise and no taping) are presented as two subgroups. The results for the two control groups of Whittingham 2004 were combined.

\section{Pain during activities or at rest}

Various pain data from four trials are presented in Analysis 1.1 using a random-effects model given the very significant heterogeneity (mean difference (MD) -0.15 ; 95\% confidence interval (CI) 1.15 to 0.85 ; heterogeneity: $\mathrm{Chi}^{2}=25.78, \mathrm{df}=4(\mathrm{P}<0.0001)$; $\mathrm{I}^{2}$ $=84 \%)$. The footnotes of Analysis 1.1 give details of the pain assessment and data for each trial. Pooled data from three of the four trials testing non-acute cases were homogeneous and also showed no significant effect, either clinical or statistical of taping on pain (see Analysis 1.2: MD 0.25; 95\% CI -0.26 to 0.77 ). The test for

Patellar taping for patellofemoral pain syndrome in adults (Review)

Copyright $\odot 2012$ The Cochrane Collaboration. Published by John Wiley \& Sons, Ltd. 
subgroup differences showed no difference between the taping on its own or when used with exercises $\left(\mathrm{Chi}^{2}=1.15, \mathrm{df}=1(\mathrm{P}=\right.$ $\left.0.28), \mathrm{I}^{2}=13.0 \%\right)$. There were no usable data from Kowall 1996, which reported that there was no difference in improvement of patellofemoral pain between the two groups at four weeks. All participants of the taping group in Whittingham 2004, which recruited people with acute knee pain, had no pain at end of treatment at four weeks. Clark 2000a found no difference between the two groups at 12 months for either comparison (see Analysis 1.3).

\section{Function and activities of daily living}

All participants of the taping group in Whittingham 2004 had no problems as rated by the functional index questionnaire (FIQ) at the end of treatment at four weeks. In contrast, the scores of both control groups indicated some residual problems with function (see Analysis 1.4). Tunay 2003 found significantly better Cincinnati knee activity scores in the taping group at the end of the three week treatment period (see Analysis 1.5: MD 8.10, 95\% CI 2.93 to 13.27). Clark 2000a found no significant differences between the two groups for either comparison in the WOMAC scores at the end of the three months treatment (see Analysis 1.6) or 12 months (see Analysis 1.7).

Clark 2000a also found no significant differences between the two groups for either comparison in post-treatment referrals (see Analysis 1.8) or further physiotherapy within 12 months (see Analysis 1.9).

There were insufficient data for any of other prespecified subgroup or sensitivity analyses.

\section{DISCUSSION}

\section{Summary of main results}

Five small heterogeneous trials, including around 200 patients (216 knees) with a diagnosis of patellofemoral pain syndrome, were included. All compared taping versus control (no or placebo taping) and all included one or more co-interventions; this was prescribed exercise in four trials. Pooled visual analogue data from four trials (161 knees) for various measures of pain at the end of treatment (this ranged from one week to three months) showed no significant benefit from taping. Separately, two trials found better results after taping for functional index questionnaire data and Cincinnati knee activity scores. Another trial found no significant benefit for taping in WOMAC scores at the end of treatment or at 12 months. The same trial also found no benefit from taping for subsequent referral or physiotherapy.

\section{Overall completeness and applicability of evidence}

The available evidence from trials testing the clinical effects of taping is little, amounting at maximum to pooled pain data for 161 knees. Even for this 'exploratory' analysis, the heterogeneous nature of the trial populations, interventions and outcome measures (both in timing and definition) is considerable.

In terms of the trial populations, there was considerable variation in the inclusion criteria and definition of patellofemoral pain syndrome among and often within the studies. The most common discrepancy was the length of time the patient had their patellofemoral pain at the time of recruitment. In one study, which involved army recruits, this was 'acute' (Whittingham 2004), whereas a lower limit of one month or more was applied for the other four studies. This means that it is possible that the patients were not comparable. Establishing inclusion and exclusion criteria for trials of patellofemoral pain syndrome will always be hampered by the lack of a gold standard diagnostic test for the condition. It remains essentially a diagnosis of exclusion reliant on description of symptoms and thorough clinical examination to exclude other causes of pain at the anterior part of the knee which are not directly related to the patellofemoral joint. Additionally, our focus was on non-arthritic patellofemoral pain but inclusion of patients with patellofemoral osteoarthritis was permitted by Mason 2011 and was likely given the older population and the long duration of symptoms (up to 15 years) in some patients.

The interventions also varied as did the co-interventions (e.g. exercise, education, ice). Some studies described in detail the method of taping used, including the technique and also the type of taping (e.g. Mason 2011), whereas others gave no description (e.g. Tunay 2003). There are anyway insufficient data to assess if there are differences in effect between a complex taping technique and a simple one. The frequency and intensity of taping (and co-interventions) also varied. Mason 2011, which compared taping versus control for one week only before moving onto a composite treatment, commented that "the objective improvement over such a short time period was unexpected”. Whittingham 2004 found complete recovery from an acute episode after four weeks in the group given taping, and good improvement too (perhaps reflecting the advice to stop certain activities) in the two control groups. This reflects also the variation in the trial populations, but also links with the assessment of outcome, which was mainly at the end of the treatment programmes. Only Clark 2000a followed up trial participants subsequently.

One finding of this review was the disappointing lack of standardisation of even a simple outcome measure such as the visual analogue score for pain. This highlights an important methodological issue for future researchers into patellofemoral pain in general and the use of patellar taping in particular. Adopting a valid, reliable and standardised pain score is the obvious aim, but true standardisation is hampered by the fact that patients may declare different pain inducing activities when they use the visual analogue 
score. These activities usually include stair ascent or descent, squatting, kneeling and prolonged sitting. There was no comparability among the trials in the use of other measures of pain and function, or the more generic self-reporting scales such as the WOMAC.

\section{Quality of the evidence}

As shown in the risk of bias summary (Figure 1), all five trials were at high of bias in least one domain, which was invariably performance bias reflecting the lack of blinding in those applying the taping and, generally, the trial participants. Poorly described or conducted randomisation, with insufficient attention to ensuring allocation concealment put three trial at high risk of selection bias. Assessor blinding, which should be possible for at least some outcomes, was not done in two studies. Unit of analysis problems, through the inclusion of patients with problems in both knees, and the incomplete information on loss to follow-up were also sources of bias. The quality of the evidence was also hampered by small sample sizes. Overall, the quality of the evidence, using the GRADE terminology, lies between 'Low quality' ("Further research is very likely to have an important impact on our confidence in the estimate of effect and is likely to change the estimate") and 'Very low quality' ("We are very uncertain about the estimate").

\section{Potential biases in the review process}

Aside from the changes, which included incorporating updated methodology described in Differences between protocol and review, this review was conducted in accordance with our previously published protocol. We took care to search extensively for studies which were in abstract form but might have proceeded to full publication. We also made great efforts (and were generally successful) to contact authors of studies which were unpublished or were uncompleted trials to ascertain whether their data could be included. Several authors confirmed points for clarification and sent additional data; most of these trials were eventually considered to be ineligible because they did not answer our research question.

\section{Agreements and disagreements with other studies or reviews}

Another review in this area has looked at the immediate (very short term effect) of patellar taping (and bracing) on knee pain with and without knee osteoarthritis (Warden 2008). There were three trials in Warden 2008 that are also included in this Cochrane review (Clark 2000a; Kowall 1996; Whittingham 2004). The outcome used for in Warden 2008 was the visual analogue scale/score (VAS) (mm) for pain, but no comment was made about the variation in the nominated activity chosen to score the VAS. Warden 2008 compared also the effects of medial directed, lateral directed patellar taping, sham taping and no taping. No analysis was performed using other measures of function or activity.

\section{AUTHORS' CONCLUSIONS}

\section{Implications for practice}

Patellar taping is a relatively inexpensive and regularly used treatment intervention for patellofemoral pain syndrome. It is frequently used as part of an exercise and rehabilitation programme for this condition. However, the currently available evidence from trials reporting clinically relevant outcomes is low quality and insufficient to draw conclusions on the effects of taping, whether used on its own or as part of a treatment programme.

\section{Implications for research}

Although the exact mechanism of patellar taping for the treatment of patellofemoral pain syndrome is unclear, it remains an attractive intervention in terms of application and potential. The low quality clinical evidence available so far does not endorse patellar taping, showing minimal evidence of any effect. It is thus timely that clinicians' enthusiasm for this intervention should be put to the test by conducting large, preferably multi-centre, good quality and well reported randomised controlled trials that measure clinically important outcomes and long-term results. Before this, consensus is required on the diagnosis of patellofemoral pain syndrome, including the avoidance of including patients with osteoarthritis, the standardisation of outcome measurement and an acceptable approach for patellar taping. Some promising progress has been made in this regard in terms of terminology, including shifting away from labelling this condition as a syndrome (Ghent 2011). These are likely to enhance the successful initiation and conduct of such trials and the acceptability and applicability of their findings.

\section{ACKNOWLEDGEMENTS}

We would like to thank Helen Handoll, Peter Herbison, David Gerrard, Lesley Gillespie, Janet Wale and Arpana Verma for their helpful comments on the protocol and subsequent review. We would also like to thank Lindsey Elstub and Joanne Elliott at the Cochrane Bone, Joint and Muscle Trauma Group. 


\section{R E F E R E N C E S}

\section{References to studies included in this review}

Clark 2000a \{published data only\}

Clark DI, Downing N, Mitchell J, Coulson L, Syzpryt EP, Doherty M. Physiotherapy for anterior knee pain: a randomised controlled trial. Annals of the Rheumatic Diseases 2000;59(9):700-4.

Kowall 1996 \{published data only\}

Kowall MG, Kolk G. Nuber GW, Cassisi JE, Stern SH. Patellar taping in the treatment of patellofemoral pain. A prospective randomized study. American Journal of Sports Medicine 1996;24(1):61-6.

Mason 2011 \{published data only\}

Mason M, Keays SL, Newcombe PA. The effect of taping, quadriceps strengthening and stretching prescribed separately or combined on patellofemoral pain. Physiotherapy Research International 2011;16(2):109-19.

Tunay 2003 \{published data only\}

Tunay VB, Baltaci G, Tunay S, Ergun N. A comparison of different treatment approaches to patellofemoral pain syndrome. Pain Clinic 2003;15(2):179-84.

Whittingham 2004 \{published data only\}

Whittingham M, Palmer S, Macmillan F. Effects of taping on pain and function in patellofemoral pain syndrome: a randomized controlled trial. Journal of Orthopaedic and Sports Physical Therapy 2004;34(9):504-10.

\section{References to studies excluded from this review}

Abd Elhafz Yehia 2011 \{published data only\}

Abd Elhafz Yehia N, Abd El Salam Mohammed S, Abd Elkader Samiha M. Taping and OKC exercises versus taping and $\mathrm{CKC}$ exercises in treating patients with patellofemoral pain syndrome. Indian Journal of Physiotherapy and Occupational Therapy 2011;5(1):103-6.

Aminaka 2008 \{published data only\} Aminaka N, Gribble PA. Patellar taping, patellofemoral pain syndrome, lower extremity kinematics, and dynamic postural control. Journal of Athletic Training 2008;43(1): 21-8.

Aminaka 2010 \{published data only\}

Aminaka N, Gribble PA. Effects of patellar taping on movement co-ordination among those with and without patellofemoral pain syndrome. Journal of Orthopaedic and Sports Physical Therapy 2010;40(3):A47.

Arcand 1998 \{published data only\} Arcand MA, Klion M. Jabbour A, Reider B, Gray D. The efficacy of McConnell taping for intermediate pain relief in patellofemoral pain syndrome: preliminary results. Journal of Bone and Joint Surgery [Br] 1998;80(Suppl 1):7-8.

Aytar 2011 \{published data only\}

Aytar A, Ozunlu N, Surenkok O, Baltaci G, Oztop P, Karatas M. Initial effects of kinesio taping in patients with patellofemoral pain syndrome: a randomized, double blind study. Isokinetic and Exercise Science 2011;19:1-8.

Bockrath 1993 \{published data only\}

Bockrath K, Wooden C, Worrell TW, Ingersoll CD, Farr J. Effects of patellar taping on patellar position and perceived pain. Medicine and Science in Sport and Exercise 1993;25 (9):989-92.

Cerny 1995a \{published data only\}

Cerny K. Vastus medialis oblique/vastus lateralis muscle activity ratios for selected exercises in persons with and without patellofemoral pain syndrome. Physical Therapy 1995;75(8):672-83.

Christou 2004 \{published data only\}

Christou EA. Patellar taping increases vastus medialis oblique activity in the presence of patellofemoral pain. Journal of Electromyography and Kinesiology 2004;14(4): 495-504.

Collins 2008 \{published data only\} Collins NJ, Collins, Natalie, Crossley, Kay, Beller, Elaine, Darnell, Ross, McPoil, Thomas, Vicenzino, Bill. Foot orthoses and physiotherapy in the treatment of patellofemoral pain syndrome: randomised clinical trial. BMJ 2008;337:1735.

Conway 1992 \{published data only\} Conway A, Malone TR, Conway P. Patellar alignment/ tracking alteration: Effect on force output and perceived pain. Isokinetics and Exercise Science 1992;2(1):9-17.

Cowan 2002b \{published data only\} Cowan SM, Bennell KL, Hodges PW. Therapeutic patellar taping changes the timing of vasti muscle activation in people with patellofemoral pain syndrome. Clinical Journal of Sport Medicine 2002;12(6):339-47.

Crome 1984 \{published data only\} Crome P, Pattison P, Kelly PS, Sommerville K. The effect of patella taping on the activation of vastus medialis oblique in subjects with retro patellar pain - a pilot study.. 10th World Congress of Physical Therapy. 1984; Vol. 2:939-43.

Crossley 2002 \{published data only\}

Cowan SM, Bennell KL, Crossley KM, Hodges PW, McConnell J. Physical therapy alters recruitment of the vasti in patellofemoral pain syndrome. Medicine and Science in Sport and Exercise 2002;34(12):1879-85.

* Crossley K, Bennell K, Green S, Cowan S, McConnell J. Physical therapy for patellofemoral pain: a randomized, double-blinded, placebo-controlled trial. American Journal of Sports Medicine 2002;30(6):857-65.

Crossley KM, Cowan SM, McConnell J, Bennell KL. Physical therapy improves knee flexion during stair ambulation in patellofemoral pain. Medicine and Science in Sport and Exercise 2005;37(2):176-83.

Derasari 2010 \{published data only\}

* Derasari A, Brindle TJ, Alter KE, Sheehan FT. McConnell taping shifts the patella inferiorly in patients with 
patellofemoral pain: A dynamic magnetic resonance imaging study. Physical Therapy 2010;90(3):411-9. Sheehan FT, Derasari A, Wilson NA, Benham AJ, Brindle TJ, Alter KE. McConnell taping shifts the patella inferiorly in the presence of patellofemoral pain. Journal of Orthopaedic and Sports Physical Therapy 2010;40(3):A37-8.

Eburne 1996 \{published data only\}

Eburne J, Bannister G. The McConnell regimen versus isometric quadriceps exercises in the management of anterior knee pain. A randomised prospective controlled trial. The Knee 1996;3(3):151-3.

Ernst 1999 \{published data only\}

Ernst GP, Kawaguchi J, Saliba E. Effect of patellar taping on knee kinetics of patients with patellofemoral pain syndrome. Journal of Orthopaedic and Sports Physical Therapy 1999;29 (11):661-7.

Gerrard 1989 \{published data only\} Gerrard B. The patello-femoral pain syndrome: a clinical trial of the McConnell programme. Australian Journal of Physiotherapy 1989;35(2):71-80.

Gilleard 1998 \{published data only\} Gilleard W, McConnell J, Parsons D. The effect of patellar taping on the onset of vastus medialis obliquus and vastus lateralis muscle activity in persons with patellofemoral pain. Physical Therapy 1988;78(1):25-32.

Handfield 2000 \{published data only\}

Handfield T, Kramer J. Effect of McConnell taping on perceived pain and knee extensor torques during isokinetic exercise performed by patients with patellofemoral pain syndrome. Physiotherapy Canada 2000;Winter(1):39-44.

Harrison 1999 \{published data only\}

Harrison EL, Sheppard MS, McQuarrie AM. A randomized controlled trial of physical therapy treatment programs in patellofemoral pain syndrome. Physiotherapy Canada 1999; 51(2):93-100.

Herrington 2001 \{published data only\} Herrington, L. The effect of patellar taping on quadriceps peak torque and perceived pain: A preliminary study. Physical Therapy in Sport 2001;2(1):23-8.

Jancaitis 2007 \{published data only\} Jancaitis GA, Kelln BM, Baker AG, Ingersoll CD, Hertel J. Short term effects of Kinesio taping on symptoms of patellofemoral pain syndrome. Journal of Athletics Training 2007;42(2 Supplement):S136-7.

Kaya 2010 \{published data only\}

Kaya D, Callaghan MJ, Ozkan H, Ozdag F, Atay OA, Yuksel I, Doral MN. The effect of an exercise program in conjunction with short-period patellar taping on pain, electromyogram activity, and muscle strength in patellofemoral pain syndrome. Sports Health 2010;2(5): 410-6.

Keet 2007 \{published data only\} Keet JHL, Gray J, Harley Y, Lambert MI. The effect of medial patellar taping on pain, strength and neuromuscular recruitment in subjects with and without patellofemoral pain. Physiotherapy 2007;93(1):45-52.

Lan 2010 \{published data only\}

Lan T-Y, Lin W-P, Jiang C-C, Chiang H. Immediate effect and predictors of effectiveness of taping for patellofemoral pain syndrome: a prospective cohort study. American Journal of Sports Medicine 2010;38(8):1626-30.

Loudon 2004 \{published data only\}

Loudon JK, Gajewski B, Goist-Foley HL, Loudon KL.

The effectiveness of exercise in treating patellofemoral pain syndrome. Journal of Sports Rehabilitation 2004;13(4): 323-42.

Mostamand 2010 \{published data only\}

Mostamand J, Bader DL, Hudson Z. The effect of patellar taping on joint reaction forces during squatting in subjects with Patellofemoral Pain Syndrome (PFPS). Journal of Bodywork \& Movement Therapies 2010;14(4):375-81.

Nafstad 1996 \{published data only\} Nafstad GL, Tronstad A, Aune AK. Patellofemoral pain syndrome: a comparative study of patella stabilising orthosis versus taping in addition to therapy practice [Patellofemorailt smertesyndrom: en sammenlignende studie av patellastabiliserende ortose versus tape som adjuvans til treningsterapi.]. Norsk Tidsskrift For Idrettsmedisin 1996;11(2):26-8.

$\mathrm{Ng} 2002$ \{published data only\}

$\mathrm{Ng}$, GY, Cheng JM. The effects of patellar taping on pain and neuromuscular performance in subjects with patellofemoral pain syndrome. Clinical Rehabilitation 2002; 16(8):821-7.

Powers 1997a \{published data only\}

Powers CM, Landel R, Sosnick T, Kirby J, Mengel $\mathrm{K}$, Cheney A, et al.The effects of patellar taping on stride characteristics and joint motion in subjects with patellofemoral pain. Journal of Orthopaedic and Sports Physical Therapy 1997;26(6):286-91.

Salsich 2002 \{published data only\} Salsich GB, Bretcher JH, Farwell D, Powers CM. The effects of patellar taping on knee kinetics, kinematics, and vastus lateralis muscle activity during stair ambulation in individuals with patellofemoral pain. Journal of Orthopaedic and Sports Physical Therapy 2002;32(1):3-10.

Selfe 2010a \{published data only\} Selfe J, Thewlis, D, Hill S, Whitaker J, Richards J. A clinical study of the biomechanics of step descent using different treatment modalities for patellofemoral pain. Journal of Orthopaedic and Sports Physical Therapy 2010;40(3):A35-6.

Somes 1997 \{published data only\}

Somes S, Worrell TW, Corey B, Ingersol CD. Effects of patellar taping on patellar position in the open and closed kinetic chain: A preliminary study. Journal of Sport Rehabilitation 1997;6(4):299-308.

Werner 1993 \{published data only\}

Werner, S, Knutsson E, Eriksson E. Effect of taping the patella on concentric and eccentric torque and EMG of knee

Patellar taping for patellofemoral pain syndrome in adults (Review)

Copyright (־ 2012 The Cochrane Collaboration. Published by John Wiley \& Sons, Ltd. 
extensor and flexor muscles in patients with patellofemoral pain syndrome. Knee Surgery, Sports Traumatology, Arthroscopy 1993;1(3-4):169-77.

Wijnen 1996 \{published data only\}

Wijnen LA, Lenssen AF, Kuys-Wouters YS, de Bie RA, Borghouts JA, Bulstra SA. McConnell therapy versus Coumans bandage in patellofemoral pain: a reandomised pilot study. [McConnell therapie versus Coumans bandage bij patellofemorale pijnklachen: een gerandomiseerde pilotstudie]. Nederlands Tijdschrift voor Fysiotherapie 1996; 106(Suppl 1 September):12-7.

Wilson 2003 \{published data only\}

Wilson T, Carter N, Thomas G. A multicenter, singlemasked study of medial, neutral, and lateral patellar taping in individuals with patellofemoral pain syndrome. Journal of Orthopaedic and Sports Physical Therapy 2003;33(8): 437-43.

\section{References to studies awaiting assessment}

\section{Miller 2010 \{published data only\}}

Miller MK, Froehling LA. An evaluation of the efficacy of 2 treatment protocols in the management of patellofemoral pain in females. Journal of Orthopaedic and Sports Physical Therapy 2010;40(3):A36-7.

\section{Additional references}

\section{Anderson 2003}

Anderson G, Herrington L. A comparison of eccentric isokinetic torque production and velocity of knee flexion angle during step down in patellofemoral pain syndrome patients and unaffected subjects. Clinical Biomechanics 2003;18(6):500-4.

\section{Brechter 2002}

Brechter JH, Powers CM. Patellofemoral stress during walking in persons with and without patellofemoral pain. Medicine \& Science in Sports \& Exercise 2002;34(10): 1582-93.

\section{Brown 2000}

Brown J. Physiotherapists' knowledge of patellofemoral pain syndrome. British Journal of Therapy and Rehabilitation 2000;7(8):346-7, 350-5.

\section{Callaghan 1996}

Callaghan MJ, Oldham JA. The role of quadriceps exercise in the treatment of patellofemoral pain syndrome. Sports Medicine 1996;21(5):384-91.

Callaghan 1997

Callaghan MJ. Patellar taping, the theory versus the evidence: a review. Physical Therapy Reviews 1997;2(4): 181-3.

Callaghan 2004 Callaghan MJ, Oldham JA. Electric muscle stimulation of the quadriceps in the treatment of patellofemoral pain. Archives of Physical Medicine and Rehabilitation 2004;85(6): 956-62.

\section{Callaghan 2007}

Callaghan MJ, Selfe J. Has the prevalence of patellofemoral pain in the general population in the United Kingdom been properly evaluated?. Physical Therapy in Sport 2007;8: $37-43$.

\section{Cerny 1995b}

Cerny K. Vastus medialis oblique/vastus lateralis muscle activity ratios for selected exercises in persons with and without patellofemoral pain syndrome. Physical Therapy 1995;75(8):672-83.

\section{Cheung 2006}

Cheung RT, Ng GY, Chen BF. Association of footwear with patellofemoral pain syndrome in runners. Sports Medicine 2006;36(3):199-205.

\section{Clark 2000b}

Clark DI, Downing N, Mitchell J, Coulson L, Syzpryt EP, Doherty M. Physiotherapy for anterior knee pain: a randomised controlled trial. Annals of the Rheumatic Diseases 2000;59(9):700-4.

\section{Crossley 2000}

Crossley K, Cowan SM, Bennell KL, McConnell J. Patellar taping: is clinical success supported by scientific evidence?. Manual Therapy 2000;5(3):142-50.

\section{Ghent 2011}

Patellofemoral Pain Syndrome: proximal, local and distal factors: An international research retreat; 2011 Aug 31 Sept 2; Ghent, Belgium. http://www.revaki.ugent.be/?q= en/pfretreat/announcement (accessed 10 Feb 2012).

\section{Goodfellow 1976}

Goodfellow J, Hungerford DS, Zindel M. Patellofemoral joint mechanics and pathology: functional anatomy of the patellofemoral joint. Journal of Bone and Joint Surgery British Volume 1976;58B(3):287-90.

\section{Grelsamer 1998}

Grelsamer RP, McConnell J. The patella. A team approach. 1st Edition. Gaithersburg: Aspen Publishers Inc, 1998.

\section{Higgins 2005}

Higgins JPT, Green S, editors. Highly sensitive search strategies for identifying reports of randomized controlled trials in MEDLINE. Cochrane Handbook for Systematic Reviews of Interventions 4.2.5 [updated May 2005]; Appendix 5. www.cochrane.org/resources/handbook/ hbook.htm (accessed 10 October 2006).

\section{Higgins 2008}

Higgins JPT, Altman DG (editors). Chapter 8: Assessing risk of bias in included studies. In: Higgins JPT, Green S (editors). Cochrane Handbook for Systematic Reviews of Interventions Version 5.0.1 (updated September 2008). The Cochrane Collaboration, 2008. Available from www.cochrane-handbook.org.

Jensen 2005

Jensen R, Hystad T, Baerheim T. Knee function and pain related to psychological variables in patients with long-term patellofemoral pain syndrome. Journal of Orthopaedic and Sports Physical Therapy 2005;35(9):594-600. 
Malek 1981

Malek MM, Mangine RE. Patellofemoral pain syndromes: a comprehensive and conservative approach. Journal of

Orthopaedic and Sports Physical Therapy 1981;2(3):108-16.

\section{McConnell 1986}

McConnell J. The management of chondromalacia patellae: a long term solution. Australian Journal of Physiotherapy 1986;32(4):215-23.

\section{McConnell 1996}

McConnell J. Management of patellofemoral problems. Manual Therapy 1996;1(2):60-6.

\section{Nimon 1998}

Nimon G, Murray D, Sandow M, Goodfellow J. Natural history of anterior knee pain: A 14 to 20 year follow-up of nonoperative management. Journal of Pediatric Orthopedics 1998;18(1):118-22.

ONS 2007

Office of National Statistics 2007. Population estimates for the United Kingdom. www.statistics.gov.uk/census2001.

\section{Powers 1997b}

Powers CM, Landel R, Sosnick T, Kirby J, Mengel $\mathrm{K}$, Cheney $\mathrm{A}$, et al.The effects of patellar taping on stride characteristics and joint motion in subjects with patellofemoral pain. Journal of Orthopaedic and Sports Physical Therapy 1997;26(6):286-291.

\section{Selfe 2004}

Selfe J. The patellofemoral joint: a review of primary research. Critical Reviews in Physical and Rehabilitation
Medicine 2004;16(1):1-30.

Selfe 2010b

Selfe J. Patellofemoral pain: myths; truths; future directions. Physiotherapy Ireland 2010;31(2):1-4.

\section{Thomas 2010}

Thomas MJ, Wood L, Selfe J, Peat G. Anterior knee pain in younger adults as a precursor to subsequent patellofemoral osteoarthritis: a systematic review. BMC Musculoskeletal Disorders 2010;11:201.

\section{Utting 2005}

Utting MR, Davies G, Newman JH. Is anterior knee pain a predisposing factor to patellofemoral osteoarthritis?. Knee 2005;12(5):362-5.

\section{Warden 2008}

Warden SJ, Hinman RS, Watson MA Jr, Avin KG, Bialocerkowski AE, Crossley KM. Patellar taping and bracing for the treatment of chronic knee pain: A systematic review and meta-analysis. Arthritis \& Rheumatism 2008;59 (1):73-83.

\section{Witvrouw 2003}

Witvrouw E, Cambier D, Danneels L, Bellemans J, Werner $S$, Almqvist F, et al.The effect of exercise regimens on reflex response time of the vasti muscles in patients with anterior knee pain: a prospective randomized intervention study. Scandinavian Journal of Medicine and Science in Sports 2003; 13(4):251-8.

* Indicates the major publication for the study 


\section{CHARACTERISTICS OFSTUDIES}

\section{Characteristics of included studies [ordered by study ID]}

\section{Clark 2000a}

Methods

Participants

Interventions

Outcomes

Notes
Observer blinded, randomised controlled trial.

\section{UK}

81 adults ( 45 male) with over 3 months of anterior knee pain. Mean age: 27.9 years (range 16 to 40 years). (Recruited from orthopaedic and rheumatology consultants and from general practitioners.) Duration of symptoms: 3 ( $<3$ months); 18 (3 to 12 months) ; 60 (> 12 months)

Inclusion criteria: a history of anterior knee pain of more than three months Exclusion criteria: a history of true locking, patella dislocation, arthritis, any knee radiograph abnormality, ligament laxity (medial and lateral collateral ligament or anterior draw test), malignancy, infection, or previous knee physiotherapy

Six treatments over period of 3 months. Length of time of each treatment not stated 1. Patellar taping, exercise \& education $(n=20)$. Tape was applied from the lateral border of the patella pulling medially and upwards over the medial femoral condyle. Taping in this way should reduce pain on the squat test and wall/step down test. If this did not eliminate the pain then the taping was repeated in knee flexion. Type of tape used is not described.

2. Exercise \& education $(n=20)$.

3. Patellar taping \& education $(\mathrm{n}=19)$. Taping as for group 1 .

4. Education $(\mathrm{n}=22)$.

Details of co-interventions

Education: leaflet "Knee pain in young adults" and sessions on (a) an explanation of the nature of anterior knee pain, the anatomy of the patellofemoral joint, and possible causes of anterior knee pain; (b) footwear and appropriate sporting activities; (c) pain controlling drugs; (d) stress relaxation techniques, ice and massage; (e) diet and weight advice; and (f) prognosis and self help.

Exercise: stretching to the hamstring, iliotibial band, quadriceps and gastrocnemius muscles. Eccentric, isotonic and isometric strengthening exercises to the lower limb

Measured at baseline, 3 months (end of treatment) and 12 months (via postal questionnaire)

Pain: two VAS: one for climbing stairs and one for flat walking. Total VAS score $=200$ $\mathrm{mm}$ (adjusted to $10 \mathrm{~cm}$ for presentation in the review)

Western Ontario and McMaster University Osteoarthritis Index (WOMAC) scores

Hospital Anxiety and Depression (HAD) scores

Quadriceps strength (Nm)

Patient satisfaction

Discharge/referral post treatment, and further physiotherapy (self-report)

Diary sheet given to help compliance.

Risk of bias 


\begin{tabular}{|c|c|c|}
\hline Bias & Authors' judgement & Support for judgement \\
\hline $\begin{array}{l}\text { Random sequence generation (selection } \\
\text { bias) }\end{array}$ & Low risk & $\begin{array}{l}\text { "The patients were then randomly allo- } \\
\text { cated by the physiotherapist to one of four } \\
\text { groups using an individualised computer } \\
\text { generated randomisation programme." }\end{array}$ \\
\hline Allocation concealment (selection bias) & Unclear risk & $\begin{array}{l}\text { Use of "individualised computer generated } \\
\text { randomisation programme", but insuffi- } \\
\text { cient description of method to ensure allo- } \\
\text { cation concealment }\end{array}$ \\
\hline $\begin{array}{l}\text { Blinding of participants and personnel } \\
\text { (performance bias) } \\
\text { All outcomes }\end{array}$ & High risk & $\begin{array}{l}\text { Participants: not done. } \\
\text { Therapists: not stated and unlikely due to } \\
\text { nature of the treatments }\end{array}$ \\
\hline $\begin{array}{l}\text { Blinding of outcome assessment (detection } \\
\text { bias) } \\
\text { All outcomes }\end{array}$ & Low risk & $\begin{array}{l}\text { "A blinded independent observer under- } \\
\text { took the assessment on the sixth visit." }\end{array}$ \\
\hline $\begin{array}{l}\text { Incomplete outcome data (attrition bias) } \\
\text { All outcomes }\end{array}$ & Low risk & $\begin{array}{l}\text { " } 10 \text { patients withdrew from the study and } \\
\text { these were included on an intention to treat } \\
\text { basis." Participant flow provided }\end{array}$ \\
\hline Other bias & Unclear risk & $\begin{array}{l}\text { Baseline characteristics of the four groups } \\
\text { were comparable. } \\
\text { "All four groups received the same advice. } \\
\text { " but lack of information on duration of } \\
\text { treatment sessions } \\
\text { Diary sheets given to help compliance in } \\
\text { exercise groups. }\end{array}$ \\
\hline
\end{tabular}

Kowall 1996

\begin{tabular}{ll}
\hline Methods & Randomised study \\
\hline Participants & USA \\
& 25 participants ( 8 male), 10 of whom had bilateral complaints (35 knees). Mean age 29 \\
& years (range 14 to 40 years). Duration of symptoms: 2.5 years (range 1 month to 15 \\
& years) \\
Inclusion criteria: unilateral or bilateral patellofemoral pain for more than 1 month, \\
patient age between 14 and 40 years, ability to complete a 4-week formal physical therapy \\
programme, and ability to comply with a 4-week home exercise programme. \\
Exclusion criteria: history or clinical evidence of patellofemoral dislocation, synovial \\
plicae, or meniscal or ligamentous injury. History of prior knee trauma or knee surgery
\end{tabular}




\section{Kowall 1996 (Continued)}

\begin{tabular}{|c|c|c|}
\hline Interventions & \multicolumn{2}{|c|}{$\begin{array}{l}\text { Treatment: twice weekly for } 4 \text { weeks } \\
\text { 1. Physical therapy and home exercise programme + patellar taping ( } \mathrm{n}=12 \text { patients) } \\
\text { Taping technique described as the 'McConnell technique'. Type of tape used is not } \\
\text { described } \\
\text { 2. Physical therapy and home exercise group without patellar taping ( } \mathrm{n}=13 \text { patients) } \\
\text { Details of co-interventions } \\
\text { Exercise: extensive stretching and quadriceps muscle-strengthening program. Quadriceps } \\
\text { muscle strengthening involved progressive isometric, isotonic, and isokinetic exercises. } \\
\text { Each group was instructed in a standard home exercise programme }\end{array}$} \\
\hline Outcomes & \multicolumn{2}{|c|}{$\begin{array}{l}\text { Measured at baseline and after } 4 \text { weeks of treatment } \\
\text { Pain during activities of daily living (VAS: } 10 \mathrm{~cm} \text { ) } \\
\text { Isokinetic quadriceps strength (Nm) } \\
\text { EMG (electromyograph) activity of the quadriceps (vastus medialis / vastus lateralis ratio) }\end{array}$} \\
\hline \multicolumn{3}{|l|}{ Notes } \\
\hline \multicolumn{3}{|l|}{ Risk of bias } \\
\hline Bias & Authors' judgement & Support for judgement \\
\hline $\begin{array}{l}\text { Random sequence generation (selection } \\
\text { bias) }\end{array}$ & Unclear risk & $\begin{array}{l}\text { "Patients meeting the eligibility requirements were randomised } \\
\text {... Randomization was accomplished with a prerandomization } \\
\text { technique in which patients were assigned to a treatment group } \\
\text { before consenting to the assigned treatment." No details of } \\
\text { method of sequence generation }\end{array}$ \\
\hline Allocation concealment (selection bias) & High risk & Not described. \\
\hline $\begin{array}{l}\text { Blinding of participants and personnel } \\
\text { (performance bias) } \\
\text { All outcomes }\end{array}$ & High risk & $\begin{array}{l}\text { Participants: not described. } \\
\text { Therapists: not possible due to the nature of the interventions }\end{array}$ \\
\hline $\begin{array}{l}\text { Blinding of outcome assessment (detection } \\
\text { bias) } \\
\text { All outcomes }\end{array}$ & High risk & Not described. \\
\hline $\begin{array}{l}\text { Incomplete outcome data (attrition bias) } \\
\text { All outcomes }\end{array}$ & High risk & $\begin{array}{l}\text { Intention-to-treat not stated. Dropouts not mentioned. Possible } \\
\text { unit of analysis problems resulting from inclusion of bilateral } \\
\text { cases }\end{array}$ \\
\hline Other bias & Unclear risk & $\begin{array}{l}\text { No data to judge baseline comparability of groups; but "The sex } \\
\text { and age of the patients and duration of symptoms were essentially } \\
\text { the same for Groups I and II." } \\
\text { Similar care programmes likely. } \\
\text { Home exercise compliance monitored with EMG, and Bio- } \\
\text { Prompt computer whilst doing exercises }\end{array}$ \\
\hline
\end{tabular}

Patellar taping for patellofemoral pain syndrome in adults (Review) 
Australia

30 knees belonging to an unknown number of participants with patellofemoral pain. Overall there were 41 participants ( 15 males, mean age 45 years, range 13 to 82 years) , 19 of whom had bilateral complaints (60 knees) recruited into the trial (see Notes). Duration of symptoms: mean 71 months

Inclusion criteria: at least 1 month of retro or peripatellar pain, aggravated by 2 or more of the following - squatting, kneeling, ascending or descending stairs, running Exclusion criteria: patellar tendinitis, Osgood-Schlatter disease, hip joint osteoarthritis, meniscal symptoms, surgery, rheumatoid arthritis, synovitis, back pain, tibiofemoral osteoarthritis

Note: Participants with patellofemoral osteoarthritis were not excluded

One week of treatment.

1. Infrapatellar taping $(\mathrm{n}=15 \mathrm{knees})$. Taping technique involved application of one layer of $50 \mathrm{~mm}$ hypoallergenic non rigid underwrap (Therfix, Physiomedic), three layers of $38 \mathrm{~mm}$ rigid zinc oxide (PhysioMed, Ausmedic). Tape applied with posterior, superior pressure under the patella

2. No treatment control ( $\mathrm{n}=15$ knees).

Details of co-interventions

Education: all trial participants received an overview of knee anatomy and function, and advice on avoiding painful activities

In the second week, all participants received a composite intervention of patellar taping, and quadriceps strengthening and stretching exercises

Outcomes

Measured at baseline and at weeks 1( post 'singular' intervention) and 2 week (post 'combined' interventions (taping, quadriceps strengthening and stretching)). Only week 1 data considered in review

VAS pain scores for 4 activities: ascent of 7 stairs without support; descent of 7 stairs without support; $18 \mathrm{~cm}$ step down leading with non-injured leg; and a self selected activity

Quadriceps strength isokinetic peak torque at $60 \%$ sec

Quadriceps tightness (length), prone lying heel to buttock distance with tape measure Pain free eccentric knee angle control test.

Data from the two other groups of this trial are not included in this review. One excluded group ( 15 knees) was given quadriceps strengthening with end range open chain knee extension; and the other group (15 knees) was given quadriceps stretching to rectus femoris in position individualised to each patient

Random group allocation was performed and allocation concealment maintained by an independent person overseeing a sealed envelope method

Patients completed a daily exercise compliance diary.

Risk of bias

Bias

Authors' judgement

Support for judgement

Patellar taping for patellofemoral pain syndrome in adults (Review) 
Random sequence generation (selection Low risk bias)
Participants were "randomly allocated to one of four groups according to a selected, sealed and pre-numbered envelope". (Details of sequence generation were, however, missing.)

"sealed and pre-numbered envelope". Not described in text but clarified as being conducted by an independent person by the lead author through personal communication (see Notes above)

Participants: not possible due to the nature of the interventions.

Therapists: the treating therapist was not blinded to the treatment grouping of the subjects

Blinding of outcome assessment (detection Low risk bias)

All outcomes

Incomplete outcome data (attrition bias) High risk All outcomes (performance bias)

All outcomes

Strategies to maintain assessor blinding described as: "All subjects were asked to wear long pants for the end of the first week assessment so that the assessing physiotherapist remained blinded towards the single modality treatment during that week."

No report of intention-to-treat analysis. No mention of drop outs. Possible unit of analysis problems resulting from inclusion of bilateral cases

Mixture of

Other bias

High risk

osteoarthritis patellofemoral pain patients with non-osteoarthritis patellofemoral pain patients. Numbers with each pathology not described. No data describing comparability of groups at entry

No information on comparability of other care but likely.

"Each subject completed a weekly exercise diary indicating the number of sessions completed each day." 


\begin{tabular}{|c|c|}
\hline Methods & Randomised study \\
\hline Participants & $\begin{array}{l}\text { Turkey } \\
40 \text { participants with unilateral patellofemoral pain syndrome (no information on gender } \\
\text { but likely to be mainly males given possible military connection). Mean age: } 30.3 \text { years. } \\
\text { Duration of symptoms: mean } 1.8 \text { years (range } 1 \text { month to } 5 \text { years) } \\
\text { Inclusion criteria: unilateral patellofemoral pain syndrome not less than } 1 \text { month } \\
\text { Exclusion criteria: history or clinical findings of patellar dislocation, meniscal or liga- } \\
\text { mentous injury, synovial plicae, knee surgery and trauma }\end{array}$ \\
\hline Interventions & $\begin{array}{l}\text { Treatment for } 3 \text { weeks }(15 \text { sessions in total }) \\
\text { 1. Patellar taping, ice and home exercises }(\mathrm{n}=20) \\
\text { 2. Ice and home exercises }(\mathrm{n}=20) \\
\text { Details of co-interventions } \\
\text { Exercise: } \text { not described. } \\
\text { Ice: } \text { not described. }\end{array}$ \\
\hline Outcomes & $\begin{array}{l}\text { Measured at baseline and after } 3 \text { weeks of treatment } \\
\text { Pain intensity (VAS: } 10 \mathrm{~cm} \text { ) } \\
\text { Cincinnati Knee Activity Rating Scale } \\
\text { Congruence angle, sulcus angle and patellar tilt angle from magnetic resonance imaging } \\
\text { (MRI) } \\
\text { The 'Q' angle } \\
\text { Hamstring and iliotibial band flexibility } \\
\text { Thigh circumference measurement } \\
\text { Leg-length discrepancy }\end{array}$ \\
\hline Notes & $\begin{array}{l}\text { Data from the two other groups of this trial are not included in this review. One of these } \\
\text { groups ( } 20 \text { participants) was given ice, electrical nerve stimulation, medial patellar glide } \\
\text { and exercise by a physiotherapist; and the other group ( } 20 \text { participants) was given ice, } \\
\text { electrical nerve stimulation, patellar taping and exercise by a physiotherapist }\end{array}$ \\
\hline
\end{tabular}

\section{Risk of bias}

\section{Bias \\ Authors' judgement Support for judgement}

Random sequence generation (selection Unclear risk bias)
"A prospective randomized study was designed ..." "The patients were divided into 4 groups matched for age and gender ....”. No details of how randomised

Allocation concealment (selection bias) High risk Not described, but use of "matching" is of concern.

Blinding of participants and personnel High risk

Participants: not described.

Therapists: not possible due to the nature of the interventions (performance bias)

All outcomes

Blinding of outcome assessment (detection High risk bias)

Evaluations were described as being "done by an orthopaedic surgeon". No other details

All outcomes 
Tunay 2003 (Continued)

\begin{tabular}{ll|l} 
Incomplete outcome data (attrition bias) Unclear risk $\quad$ Intention-to-treat not mentioned. Unclear if there are drop outs
\end{tabular} All outcomes

Other bia

Unclear risk

Comparable baseline characteristics.

Lack of information to judge performance bias from differences in other care

No compliance monitoring

Whittingham 2004

\begin{tabular}{|c|c|}
\hline Methods & Randomised controlled trial \\
\hline Participants & $\begin{array}{l}\text { UK (military) } \\
30 \text { (male = 24) army recruits with a diagnosis of acute patellofemoral pain syndrome } \\
\text { referred for physiotherapy by the Unit Medical Officer. Mean age } 18.7 \text { years. Duration } \\
\text { of symptoms: acute } \\
\text { Inclusion criteria: recruits with two from the following - pain on ascending and/or } \\
\text { descending stairs, squatting, sitting for extended periods of time, or associated with an } \\
\text { increase in physical activity. Aged } 17 \text { to } 25 \text { years, and able to give informed consent } \\
\text { Exclusion criteria: history of subluxation or dislocation of the patella, anterior or poste- } \\
\text { rior cruciate ligament insufficiency, previous knee surgery or meniscal damage, or any } \\
\text { other underlying musculoskeletal problems that would have prevented the subject from } \\
\text { performing the exercises }\end{array}$ \\
\hline Interventions & $\begin{array}{l}\text { Treatment for } 4 \text { weeks; daily sessions (no home exercises) } \\
\text { 1. Patella taping and a standardised exercise programme }(\mathrm{n}=10) \text {. Active taping technique: } \\
\text { underwrap and one corrective strip of tape. Correction of patellar malalignments of tilt, } \\
\text { rotation or glide as identified by the treating physiotherapist } \\
\text { 2. Placebo taping and the same exercise programme }(\mathrm{n}=10) \text {. Placebo taping: underwrap } \\
\text { and one strip of tape with no correction of patellar position } \\
\text { 3. Same exercise programme alone }(\mathrm{n}=10) \\
\text { Type of adhesive tape not described. } \\
\text { Details of co-interventions } \\
\text { Exercise: non-weight-bearing isometric, inner-range isotonic and straight leg raise quadri- } \\
\text { ceps exercises. A variety of weight-bearing exercises (e.g. squats). Stretches for the quadri- } \\
\text { ceps, hamstrings, gastrocnemius, and iliotibial band. No home exercise programme }\end{array}$ \\
\hline
\end{tabular}

Outcomes

Measured at baseline and at weeks 1, 2, 3 and 4 during treatment

VAS pain scores $(10 \mathrm{~cm})$ : average over last 24 hours; during stepping down activity with tape and without tape applied

Functional index questionnaire

Notes

Risk of bias

Bias

Authors' judgement

Support for judgement

Patellar taping for patellofemoral pain syndrome in adults (Review)

Copyright (־ 2012 The Cochrane Collaboration. Published by John Wiley \& Sons, Ltd. 


\section{Whittingham 2004 (Continued)}

\begin{tabular}{|c|c|c|}
\hline $\begin{array}{l}\text { Random sequence generation (selection } \\
\text { bias) }\end{array}$ & Low risk & $\begin{array}{l}\text { "A block randomisation process was used, where subjects } \\
\text { randomly chose } 1 \text { of } 3 \text { labelled envelopes to determine } \\
\text { their group allocation. The next subject chose } 1 \text { of the } \\
\text { remaining } 2 \text { envelopes and the third person was then } \\
\text { assigned to the remaining group before the process was } \\
\text { repeated. This ensured that there were even numbers of } \\
\text { subjects in each group." }\end{array}$ \\
\hline Allocation concealment (selection bias) & High risk & $\begin{array}{l}\text { As described above. The allocation was not concealed for } \\
\text { every third patient }\end{array}$ \\
\hline $\begin{array}{l}\text { Blinding of participants and personnel } \\
\text { (performance bias) } \\
\text { All outcomes }\end{array}$ & High risk & $\begin{array}{l}\text { Participants: not possible due to the nature of the inter- } \\
\text { ventions } \\
\text { Therapists: the treating therapist, "who was aware of } \\
\text { group allocation, applied adhesive tape to the affected } \\
\text { knee of subjects in the taping group and placebo taping } \\
\text { group" }\end{array}$ \\
\hline $\begin{array}{l}\text { Blinding of outcome assessment (detection } \\
\text { bias) } \\
\text { All outcomes }\end{array}$ & Low risk & $\begin{array}{l}\text { The assessor, who was blinded to group allocation, took } \\
\text { all outcome measures }\end{array}$ \\
\hline $\begin{array}{l}\text { Incomplete outcome data (attrition bias) } \\
\text { All outcomes }\end{array}$ & Low risk & $\begin{array}{l}\text { "All subjects remained in the group to which they were } \\
\text { originally assigned." }\end{array}$ \\
\hline Other bias & Low risk & $\begin{array}{l}\text { Baseline characteristics comparable in the three groups. } \\
\text { "All subjects were placed on restricted duties (similar for } \\
\text { all individuals) throughout the treatment period." Every } \\
\text { participant attended daily at the same time for } 4 \text { weeks } \\
\text { duration of the study (study was in a military setting) } \\
\text { No home exercise programme prescribed and exercise } \\
\text { compliance not needed }\end{array}$ \\
\hline
\end{tabular}

\section{Characteristics of excluded studies [ordered by study ID]}

Study Reason for exclusion

Abd Elhafz Yehia 2011 This study was excluded because it compared open versus closed kinetic exercises; both groups received taping

Aminaka 2008 The trial assessed the effect of taping on pain immediately post application and not as part of a treatment programme

Aminaka 2010

Published abstract with immediate pre and post taping effect 
(Continued)

\begin{tabular}{|c|c|}
\hline Arcand 1998 & Abstract with immediate pre and post taping effect. \\
\hline Aytar 2011 & $\begin{array}{l}\text { The trial assessed patients within } 45 \text { minutes of application of the tape and not as part of a treatment } \\
\text { programme }\end{array}$ \\
\hline Bockrath 1993 & $\begin{array}{l}\text { The trial assessed the effect of taping on pain immediately post application and not as part of a treatment } \\
\text { programme }\end{array}$ \\
\hline Cerny 1995a & $\begin{array}{l}\text { The trial assessed the effect of taping on pain immediately post application and not as part of a treatment } \\
\text { programme }\end{array}$ \\
\hline Christou 2004 & $\begin{array}{l}\text { The trial assessed the effect of taping on pain immediately post application and not as part of a treatment } \\
\text { programme }\end{array}$ \\
\hline Collins 2008 & $\begin{array}{l}\text { This was a single blinded randomised clinical trial primarily assessing foot orthotics. There was a group } \\
\text { that had taping, but also had multimodal physiotherapy including stretching, exercise, education and } \\
\text { biofeedback. Therefore it was difficult to guarantee that taping alone would cause the beneficial effect found } \\
\text { in the study }\end{array}$ \\
\hline Conway 1992 & $\begin{array}{l}\text { The trial assessed the effect of taping on pain immediately post application and not as part of a treatment } \\
\text { programme }\end{array}$ \\
\hline Cowan 2002b & $\begin{array}{l}\text { The trial assessed the effect of taping on pain immediately post application and not as part of a treatment } \\
\text { programme }\end{array}$ \\
\hline
\end{tabular}

Crome 1984 Abstract. The trial assessed the effect of taping on pain immediately post application and not as part of a treatment programme

Crossley 2002 This trial compared physical therapy, which included patellar taping, versus placebo therapy, which included placebo taping. It is excluded because it would be impossible to attribute the results to patellar taping alone

Derasari 2010 The trial assessed the effect of taping on kinematically assessed patellar position immediately post application and not as part of a treatment programme

Eburne 1996 Group 1 received no tape and Group 2 received tape. However, the two groups received different exercise regimens. So this study was excluded as the two programmes were substantially different to be certain that the differences were solely due to the allocation of tape

Ernst 1999

The trial assessed the effect of taping on pain immediately post application and not as part of a treatment programme

Gerrard 1989

The study was an uncontrolled, non-randomised trial of taping as part of an exercise programme

Gilleard 1998

The trial assessed the effect of taping on pain immediately post application and not as part of a treatment programme 
(Continued)

\begin{tabular}{ll}
\hline Handfield 2000 & $\begin{array}{l}\text { The trial assessed the effect of taping on pain immediately and } 24 \text { hours post application and not as part of } \\
\text { a treatment programme }\end{array}$ \\
\hline Harrison 1999 & $\begin{array}{l}\text { This study was excluded because Group 2 received education and a strength and stretching programme but } \\
\text { Group 3 received not only taping additionally, but also biofeedback. Therefore it cannot be guaranteed that } \\
\text { taping was the sole different intervention between the groups }\end{array}$ \\
\hline Herrington 2001 & $\begin{array}{l}\text { The trial assessed the effect of taping on pain immediately post application and not as part of a treatment } \\
\text { programme }\end{array}$ \\
\hline Jancaitis 2007 & $\begin{array}{l}\text { Abstract. Two days of taping versus sham taping. Personal communication with author revealed that data } \\
\text { were not available for fuller analysis }\end{array}$ \\
\hline Kaya 2010 & $\begin{array}{l}\text { Although this has a three month patellar taping programme, all patellofemoral pain syndrome patients } \\
\text { received taping. This is a within-group trial using the healthy knee for comparison and with a healthy control } \\
\text { group }\end{array}$ \\
\hline
\end{tabular}

Keet 2007

The trial assessed the effect of taping on pain immediately post application and not as part of a treatment programme

Lan 2010

The trial assessed the effect of taping on pain immediately post application and not as part of a treatment programme

Loudon 2004

Although this was an eight week exercise programme, it was excluded because all groups including the control group received patellar taping

Mostamand 2010

The trial assessed the effect of taping on pain immediately post application and not as part of a treatment programme

Nafstad 1996

This study was excluded because it compared exercise plus tape versus exercise plus elastic patellar brace

$\operatorname{Ng} 2002$

The trial assessed the effect of taping on pain immediately post application and not as part of a treatment programme

Powers $1997 \mathrm{a}$

The trial assessed the effect of taping on pain immediately post application and not as part of a treatment programme

Salsich 2002

The trial assessed the effect of taping on pain immediately post application and not as part of a treatment programme

Selfe 2010a

Abstract reporting immediate pre and post taping effect only

Somes 1997

The trial assessed the effect of taping on pain immediately post application and not as part of a treatment programme

Werner 1993

The trial assessed the effect of taping on pain immediately post application and not as part of a treatment programme 
(Continued)

Wijnen 1996

This was excluded for two reasons. Firstly, it compared patellar taping with an elasticated knee bandage so there was no 'no-taping' group. Secondly it was not possible to ascertain if the exercise programmes for both groups were comparable as there were no details for the programme given to the 'Couman group'

Wilson 2003

The trial assessed the effect of taping on pain immediately post application and not as part of a treatment programme

\section{Characteristics of studies awaiting assessment [ordered by study ID]}

\section{Miller 2010}

\begin{tabular}{ll}
\hline Methods & Randomised controlled trial \\
\hline Participants & $\begin{array}{l}\text { Females with unilateral or bilateral patellofemoral pain syndrome. History of patellofemoral pain over a period of six } \\
\text { weeks; "top scores from patellar orientation tests" }\end{array}$ \\
\hline Interventions & $\begin{array}{l}\text { 8 week treatment period } \\
\text { 1. Taping plus exercise } \\
\text { 2. Exercise only }\end{array}$ \\
\hline Outcomes & $\begin{array}{l}\text { Measured at weeks } 1,4 \text { and } 8 \text { weeks } \\
\text { Pain, functional activity. }\end{array}$ \\
\hline Notes & $\begin{array}{l}\text { Abstract only. Thirty volunteers but probably fewer after tests; also a third group (no treatment control) is not eligible } \\
\text { for this review. The numbers randomised into the three groups are not reported }\end{array}$ \\
\hline
\end{tabular}


DATA AND ANALYSES

\section{Comparison 1. Patellar taping versus no or placebo taping}

\begin{tabular}{|c|c|c|c|c|}
\hline Outcome or subgroup title & $\begin{array}{l}\text { No. of } \\
\text { studies }\end{array}$ & $\begin{array}{c}\text { No. of } \\
\text { participants }\end{array}$ & Statistical method & Effect size \\
\hline $\begin{array}{l}1 \text { Pain: VAS (0: no pain to } 10 \text { : } \\
\text { worst pain) at end of treatment }\end{array}$ & 4 & 161 & Mean Difference (IV, Random, 95\% CI) & $-0.15[-1.15,0.85]$ \\
\hline $\begin{array}{l}1.1 \text { No exercise } \\
\text { co-intervention }\end{array}$ & 2 & 62 & Mean Difference (IV, Random, 95\% CI) & $-0.10[-0.91,0.72]$ \\
\hline $\begin{array}{l}\text { 1.2 Same exercises given to all } \\
\text { participants }\end{array}$ & 3 & 99 & Mean Difference (IV, Random, 95\% CI) & $-0.16[-1.67,1.34]$ \\
\hline $\begin{array}{l}2 \text { Pain: VAS (0: no pain to } 10 \text { : } \\
\text { worst pain) at end of treatment } \\
\text { (no 'acute' cases) }\end{array}$ & 3 & 141 & Mean Difference (IV, Fixed, 95\% CI) & $0.25[-0.26,0.77]$ \\
\hline $\begin{array}{l}2.1 \text { No exercise } \\
\text { co-intervention }\end{array}$ & 2 & 62 & Mean Difference (IV, Fixed, 95\% CI) & $-0.10[-0.91,0.72]$ \\
\hline $\begin{array}{l}2.2 \text { Same exercises given to all } \\
\text { participants }\end{array}$ & 2 & 79 & Mean Difference (IV, Fixed, 95\% CI) & $0.48[-0.18,1.14]$ \\
\hline $\begin{array}{l}3 \text { Pain: VAS (0: no pain to } 10 \text { : } \\
\text { worst pain) at } 12 \text { months }\end{array}$ & 1 & & Mean Difference (IV, Fixed, 95\% CI) & Totals not selected \\
\hline $\begin{array}{l}3.1 \text { No exercise } \\
\text { co-intervention }\end{array}$ & 1 & & Mean Difference (IV, Fixed, 95\% CI) & $0.0[0.0,0.0]$ \\
\hline $\begin{array}{l}3.2 \text { Same exercises given to all } \\
\text { participants }\end{array}$ & 1 & & Mean Difference (IV, Fixed, 95\% CI) & $0.0[0.0,0.0]$ \\
\hline $\begin{array}{l}4 \text { Functional index questionnaire } \\
\text { (FIQ) score }(16=\text { no problems }) \\
\text { at end of treatment }\end{array}$ & 1 & & Mean Difference (IV, Fixed, 95\% CI) & Totals not selected \\
\hline $\begin{array}{l}\text { 4.1 No exercise co- } \\
\text { intervention }\end{array}$ & 0 & & Mean Difference (IV, Fixed, 95\% CI) & $0.0[0.0,0.0]$ \\
\hline $\begin{array}{l}4.2 \text { Same exercises given to all } \\
\text { participants }\end{array}$ & 1 & & Mean Difference (IV, Fixed, 95\% CI) & $0.0[0.0,0.0]$ \\
\hline $\begin{array}{l}5 \text { Cincinnati knee activity score } \\
(100=\text { full activity }) \text { at end of } \\
\text { treatment }\end{array}$ & 1 & & Mean Difference (IV, Fixed, 95\% CI) & Totals not selected \\
\hline $\begin{array}{l}5.1 \text { No exercise co- } \\
\text { intervention }\end{array}$ & 0 & & Mean Difference (IV, Fixed, 95\% CI) & $0.0[0.0,0.0]$ \\
\hline $\begin{array}{l}5.2 \text { Same exercises given to all } \\
\text { participants }\end{array}$ & 1 & & Mean Difference (IV, Fixed, 95\% CI) & $0.0[0.0,0.0]$ \\
\hline $\begin{array}{l}6 \text { WOMAC score (0: no problems } \\
\text { to } 96 \text { : extreme problems) at } \\
\text { end of treatment }\end{array}$ & 1 & & Mean Difference (IV, Fixed, 95\% CI) & Totals not selected \\
\hline $\begin{array}{l}\text { 6.1 No exercise } \\
\text { co-intervention }\end{array}$ & 1 & & Mean Difference (IV, Fixed, 95\% CI) & $0.0[0.0,0.0]$ \\
\hline $\begin{array}{l}6.2 \text { Same exercises given to all } \\
\text { participants }\end{array}$ & 1 & & Mean Difference (IV, Fixed, 95\% CI) & $0.0[0.0,0.0]$ \\
\hline
\end{tabular}

Patellar taping for patellofemoral pain syndrome in adults (Review)

Copyright $\odot 2012$ The Cochrane Collaboration. Published by John Wiley \& Sons, Ltd. 
7 WOMAC score (0: no problems

to 96 : extreme problems) at 12 months

\begin{tabular}{|c|c|c|c|}
\hline $\begin{array}{l}\text { 7.1 No exercise } \\
\text { co-intervention }\end{array}$ & 1 & Mean Difference (IV, Fixed, 95\% CI) & $0.0[0.0,0.0]$ \\
\hline $\begin{array}{l}7.2 \text { Same exercises given to all } \\
\text { participants }\end{array}$ & 1 & Mean Difference (IV, Fixed, 95\% CI) & $0.0[0.0,0.0]$ \\
\hline $\begin{array}{l}\text { Referred for further treatment } \\
\text { (after } 3 \text { months) }\end{array}$ & 1 & Risk Ratio (M-H, Fixed, 95\% CI) & Totals not selected \\
\hline $\begin{array}{l}8.1 \text { No exercise } \\
\text { co-intervention }\end{array}$ & 1 & Risk Ratio (M-H, Fixed, 95\% CI) & $0.0[0.0,0.0]$ \\
\hline $\begin{array}{l}8.2 \text { Same exercises given to all } \\
\text { participants }\end{array}$ & 1 & Risk Ratio (M-H, Fixed, 95\% CI) & $0.0[0.0,0.0]$ \\
\hline $\begin{array}{l}\text { Further course of physiotherapy } \\
\text { (after } 3 \text { months) }\end{array}$ & 1 & Risk Ratio (M-H, Fixed, 95\% CI) & Totals not selected \\
\hline $\begin{array}{l}9.1 \text { No exercise } \\
\text { co-intervention }\end{array}$ & 1 & Risk Ratio (M-H, Fixed, 95\% CI) & $0.0[0.0,0.0]$ \\
\hline $\begin{array}{l}9.2 \text { Same exercises given to all } \\
\text { participants }\end{array}$ & 1 & Risk Ratio (M-H, Fixed, 95\% CI) & $0.0[0.0,0.0]$ \\
\hline
\end{tabular}

\section{Analysis I.I. Comparison I Patellar taping versus no or placebo taping, Outcome I Pain: VAS (0: no pain to I0: worst pain) at end of treatment.}

Review: Patellar taping for patellofemoral pain syndrome in adults

Comparison: I Patellar taping versus no or placebo taping

Outcome: I Pain: VAS (0: no pain to 10: worst pain) at end of treatment

\begin{tabular}{|c|c|c|c|c|c|c|c|}
\hline \multirow[t]{2}{*}{ Study or subgroup } & \multirow{2}{*}{$\begin{array}{r}\text { Tape } \\
\mathrm{N}\end{array}$} & \multicolumn{3}{|c|}{ No or placebo tape } & \multirow{2}{*}{$\begin{array}{c}\text { Mean } \\
\text { Difference } \\
\text { IV,Random,95\% Cl }\end{array}$} & \multirow[t]{2}{*}{ Weight } & \multirow{2}{*}{$\begin{array}{r}\text { Mean } \\
\text { Difference } \\
\text { IV,Random,95\% Cl }\end{array}$} \\
\hline & & Mean(SD) & $\mathrm{N}$ & Mean(SD) & & & \\
\hline \multicolumn{8}{|c|}{ I No exercise co-intervention } \\
\hline Clark 2000a (I) & 16 & $1.8(1.44)$ & 16 & $1.5(2)$ & 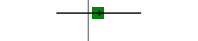 & $18.2 \%$ & $0.30[-0.9|| .5 \mid]$, \\
\hline Mason 2011 (2) & 15 & $1.83(1.6)$ & 15 & $2.26(1.5)$ & $\longrightarrow$ & $19.0 \%$ & $-0.43[-1.54,0.68]$ \\
\hline Subtotal (95\% CI) & 31 & & 31 & & & $37.1 \%$ & $-0.10[-0.91,0.72]$ \\
\hline \multicolumn{8}{|c|}{ Heterogeneity: Tau?? = 0.0; Chi?? =0.76, df = I (P=0.38); $1 ? ?=0.0 \%$} \\
\hline \multicolumn{8}{|c|}{ Test for overall effect: $Z=0.23(P=0.82)$} \\
\hline \multicolumn{8}{|c|}{2 Same exercises given to all participants } \\
\hline Clark 2000a (3) & 18 & $2.89(1.94)$ & 21 & $2.08(2.03)$ & $\square$ & $17.9 \%$ & $0.81[-0.44,2.06]$ \\
\hline Tunay 2003 (4) & 20 & $2.7(1.38)$ & 20 & $2.35(1.13)$ & $\longrightarrow$ & $21.5 \%$ & $0.35[-0.43,1.13]$ \\
\hline Whittingham 2004 (5) & 10 & $0(0.1)$ & 10 & $1.45(0.73)$ & 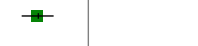 & $23.5 \%$ & $-1.45[-1.91,-0.99]$ \\
\hline Subtotal (95\% CI) & 48 & & 51 & & & $62.9 \%$ & $-0.16[-1.67,1.34]$ \\
\hline \multicolumn{8}{|c|}{ Heterogeneity: Tau?? = 1.57; Chi?? = 22.47, df = $2(P=0.00001) ; 1 ? ?=91 \%$} \\
\hline \multicolumn{8}{|c|}{ (5) Pain on step down. 0.1 added in as SD for Tape group to show data. At 4 weeks. } \\
\hline & & & & & & & (Continued ... ) \\
\hline
\end{tabular}

Copyright (־ 2012 The Cochrane Collaboration. Published by John Wiley \& Sons, Ltd. 


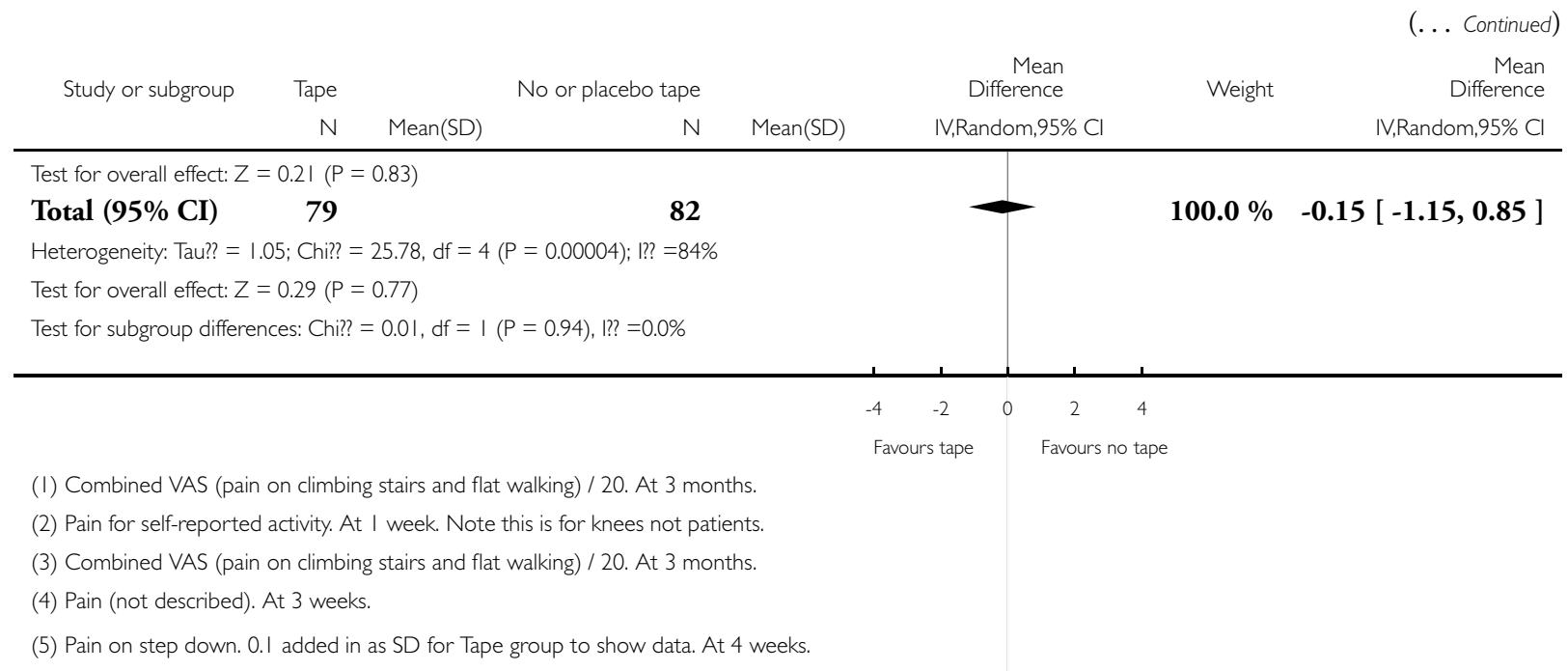

Analysis I.2. Comparison I Patellar taping versus no or placebo taping, Outcome 2 Pain: VAS (0: no pain to I0: worst pain) at end of treatment (no 'acute' cases).

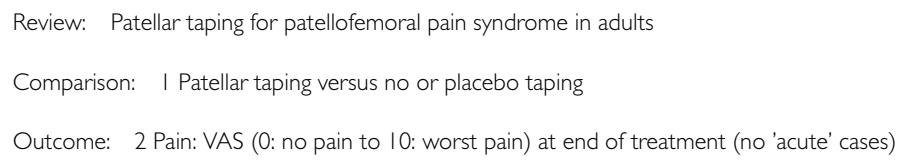

\begin{tabular}{|c|c|c|c|c|c|c|c|}
\hline \multirow[t]{2}{*}{ Study or subgroup } & \multirow{2}{*}{$\begin{array}{r}\text { Tape } \\
\text { N }\end{array}$} & \multicolumn{2}{|r|}{ No or placebo tape } & \multicolumn{2}{|r|}{$\begin{array}{r}\text { Mean } \\
\text { Difference }\end{array}$} & \multirow[t]{2}{*}{ Weight } & \multirow{2}{*}{ 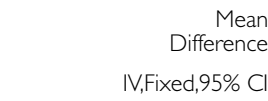 } \\
\hline & & Mean(SD) & $\mathrm{N}$ & Mean(SD) & IV,Fixed,95\% Cl & & \\
\hline \multicolumn{8}{|c|}{ I No exercise co-intervention } \\
\hline Clark 2000a & 16 & $1.8(1.44)$ & 16 & $1.5(2)$ & $=$ & $18.2 \%$ & $0.30[-0.91,1.51]$ \\
\hline Mason 2011 & 15 & $1.83(1.6)$ & 15 & $2.26(1.5)$ & $\longrightarrow$ & $21.5 \%$ & $-0.43[-1.54,0.68]$ \\
\hline Subtotal $(95 \% \mathrm{CI})$ & 31 & & 31 & & - & $39.7 \%$ & $-0.10[-0.91,0.72]$ \\
\hline \multicolumn{8}{|c|}{ Heterogeneity: Chin? $=0.76, \mathrm{df}=\mathrm{I}(\mathrm{P}=0.38) ; 1 ? ?=0.0 \%$} \\
\hline \multicolumn{8}{|c|}{ Test for overall effect: $Z=0.23(P=0.82)$} \\
\hline \multicolumn{8}{|c|}{2 Same exercises given to all participants } \\
\hline Clark 2000a & 18 & $2.89(1.94)$ & 21 & $2.08(2.03)$ & $\rightarrow$ & $17.0 \%$ & $0.81[-0.44,2.06]$ \\
\hline Tunay 2003 & 20 & $2.7(1.38)$ & 20 & $2.35(1.13)$ & $\rightarrow-$ & $43.3 \%$ & $0.35[-0.43,1.13]$ \\
\hline \multirow[t]{3}{*}{ Subtotal $(95 \%$ CI) } & 38 & & 41 & & & $60.3 \%$ & $0.48[-0.18,1.14]$ \\
\hline & & & & & -2 & 4 & \\
\hline & & & & & Favours tape & tape & \\
\hline
\end{tabular}




\begin{tabular}{|c|c|c|c|c|c|c|c|}
\hline \multirow[t]{2}{*}{ Study or subgroup } & Tape & \multicolumn{3}{|c|}{ No or placebo tape } & \multirow{2}{*}{$\begin{array}{c}\text { Mean } \\
\text { Difference } \\
\text { IV,Fixed,95\% Cl }\end{array}$} & \multirow[t]{2}{*}{ Weight } & \multirow{2}{*}{$\begin{array}{r}\text { (... Continued }) \\
\text { Mean } \\
\text { Difference } \\
\text { IV,Fixed,95\% Cl }\end{array}$} \\
\hline & $\mathrm{N}$ & Mean(SD) & $\mathrm{N}$ & Mean(SD) & & & \\
\hline \multicolumn{8}{|c|}{ Heterogeneity: Chin? $=0.37, \mathrm{df}=\mathrm{I}(\mathrm{P}=0.54) ; \mathrm{l} ?=0.0 \%$} \\
\hline \multicolumn{8}{|c|}{ Test for overall effect: $Z=1.42(P=0.16)$} \\
\hline Total $(95 \% \mathrm{CI})$ & 69 & & 72 & & - & $100.0 \%$ & $0.25[-0.26,0.77]$ \\
\hline \multicolumn{8}{|c|}{ Heterogeneity: Chi?? $=2.29, \mathrm{df}=3(\mathrm{P}=0.52) ; 1 ?$ ? $=0.0 \%$} \\
\hline \multicolumn{8}{|c|}{ Test for overall effect: $Z=0.96(P=0.34)$} \\
\hline \multicolumn{8}{|c|}{ Test for subgroup differences: Chi?? $=1.15, \mathrm{df}=1(P=0.28), 1 ? ?=13 \%$} \\
\hline
\end{tabular}

\section{Analysis I.3. Comparison I Patellar taping versus no or placebo taping, Outcome 3 Pain: VAS (0: no pain to} 10: worst pain) at 12 months.

Review: Patellar taping for patellofemoral pain syndrome in adults

Comparison: I Patellar taping versus no or placebo taping

Outcome: 3 Pain: VAS (0: no pain to 10: worst pain) at 12 months

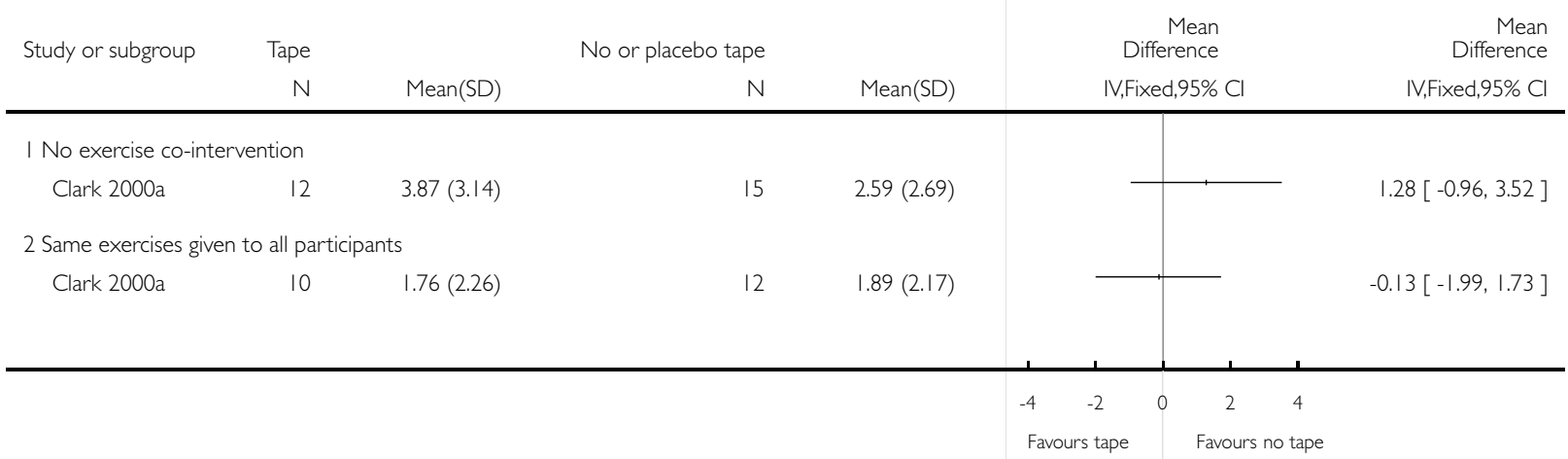


Analysis I.4. Comparison I Patellar taping versus no or placebo taping, Outcome 4 Functional index questionnaire (FIQ) score ( 16 = no problems) at end of treatment.

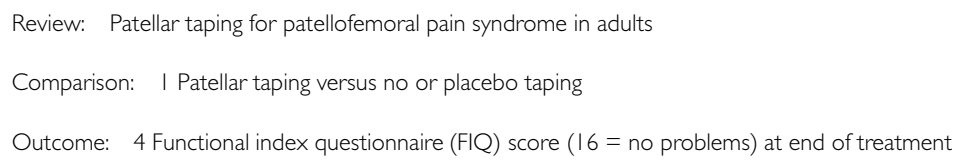

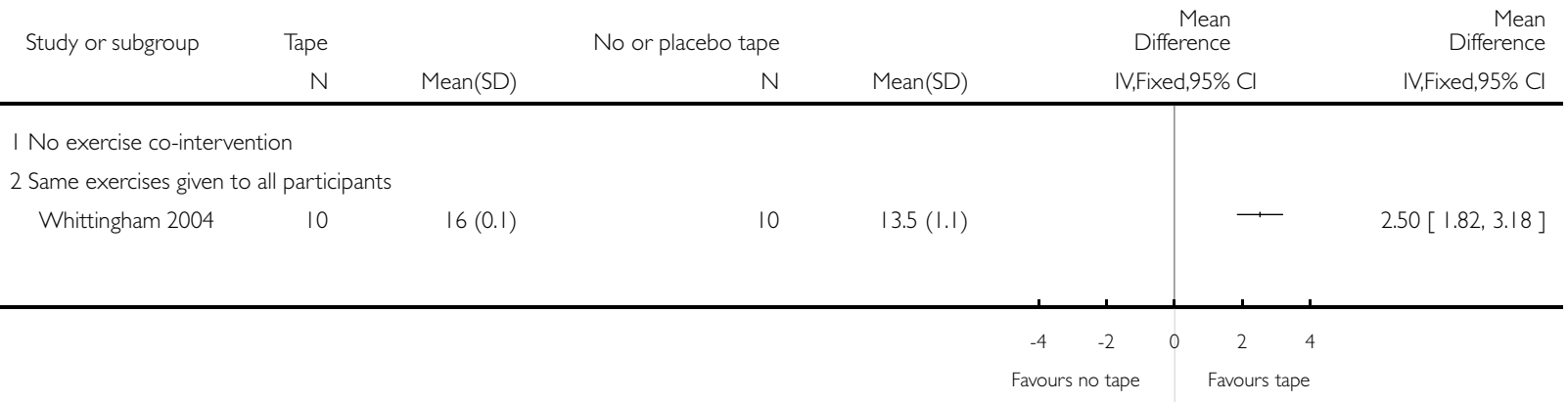

Analysis I.5. Comparison I Patellar taping versus no or placebo taping, Outcome 5 Cincinnati knee activity score ( $100=$ full activity $)$ at end of treatment.

Review: Patellar taping for patellofemoral pain syndrome in adults

Comparison: I Patellar taping versus no or placebo taping

Outcome: 5 Cincinnati knee activity score (100 = full activity) at end of treatment

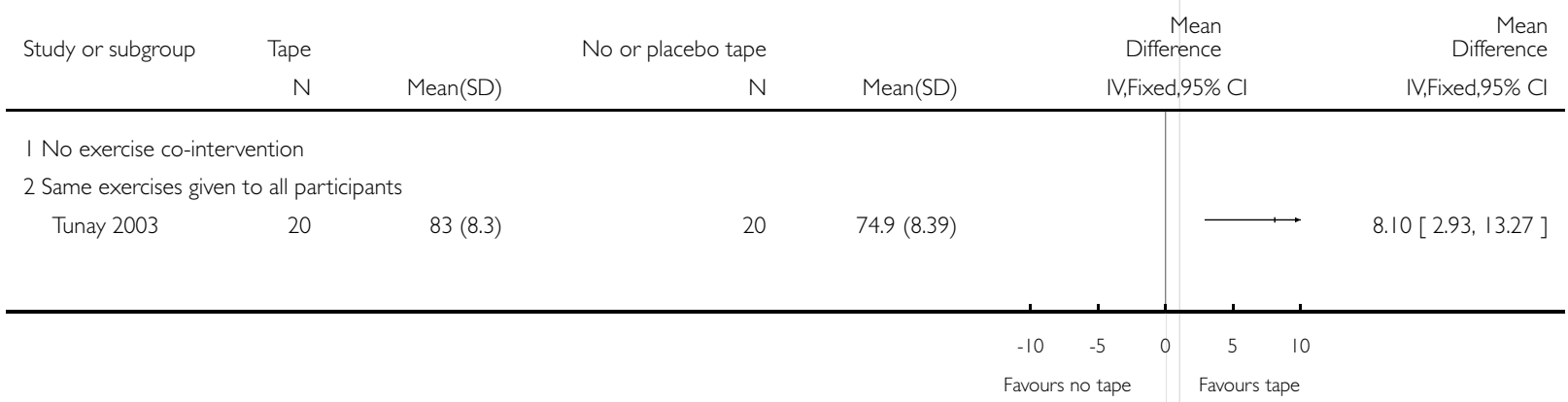


Analysis 1.6. Comparison I Patellar taping versus no or placebo taping, Outcome 6 WOMAC score (0: no problems to 96: extreme problems) at end of treatment.

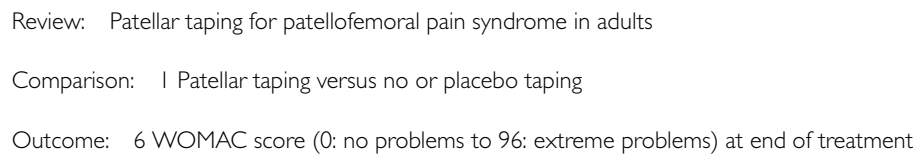

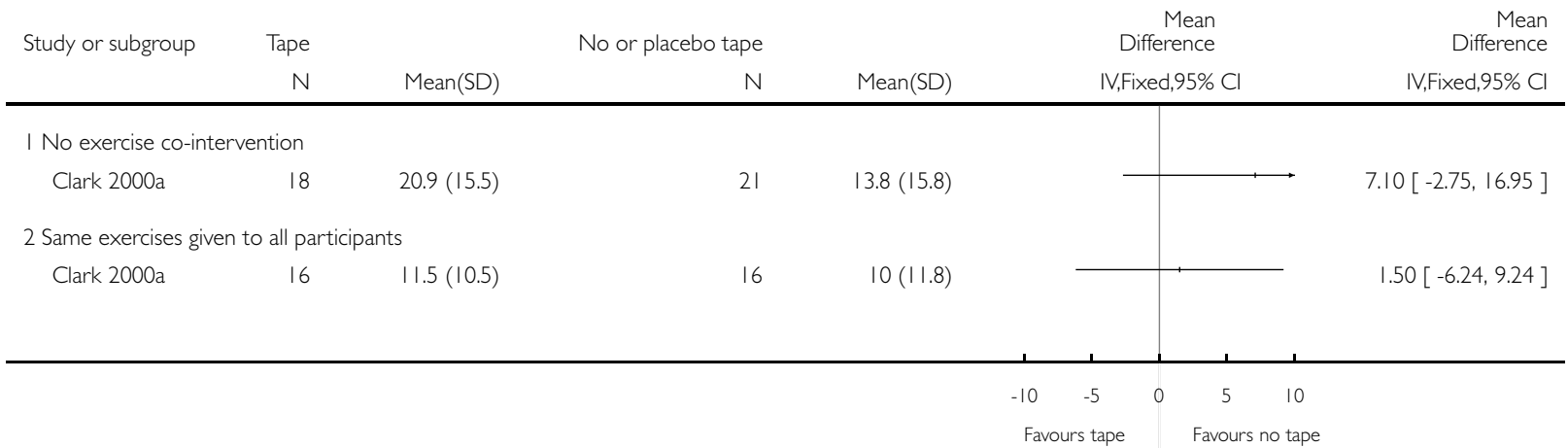

Analysis I.7. Comparison I Patellar taping versus no or placebo taping, Outcome 7 WOMAC score (0: no problems to 96: extreme problems) at 12 months.

Review: Patellar taping for patellofemoral pain syndrome in adults

Comparison: I Patellar taping versus no or placebo taping

Outcome: 7 WOMAC score (0: no problems to 96: extreme problems) at 12 months

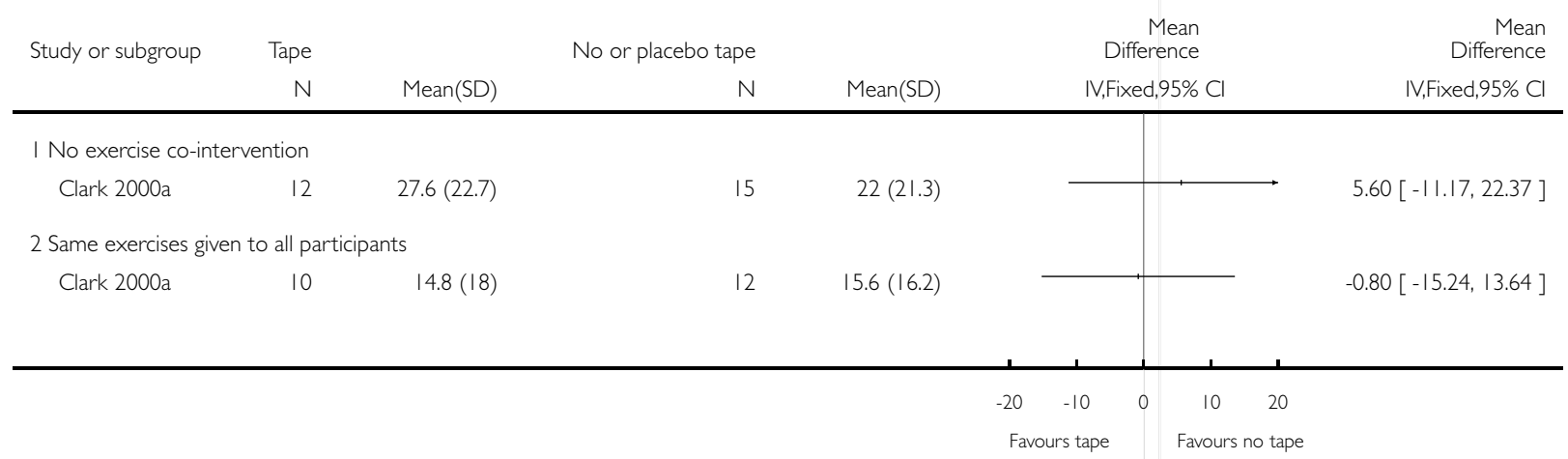


Analysis I.8. Comparison I Patellar taping versus no or placebo taping, Outcome 8 Referred for further treatment (after 3 months).

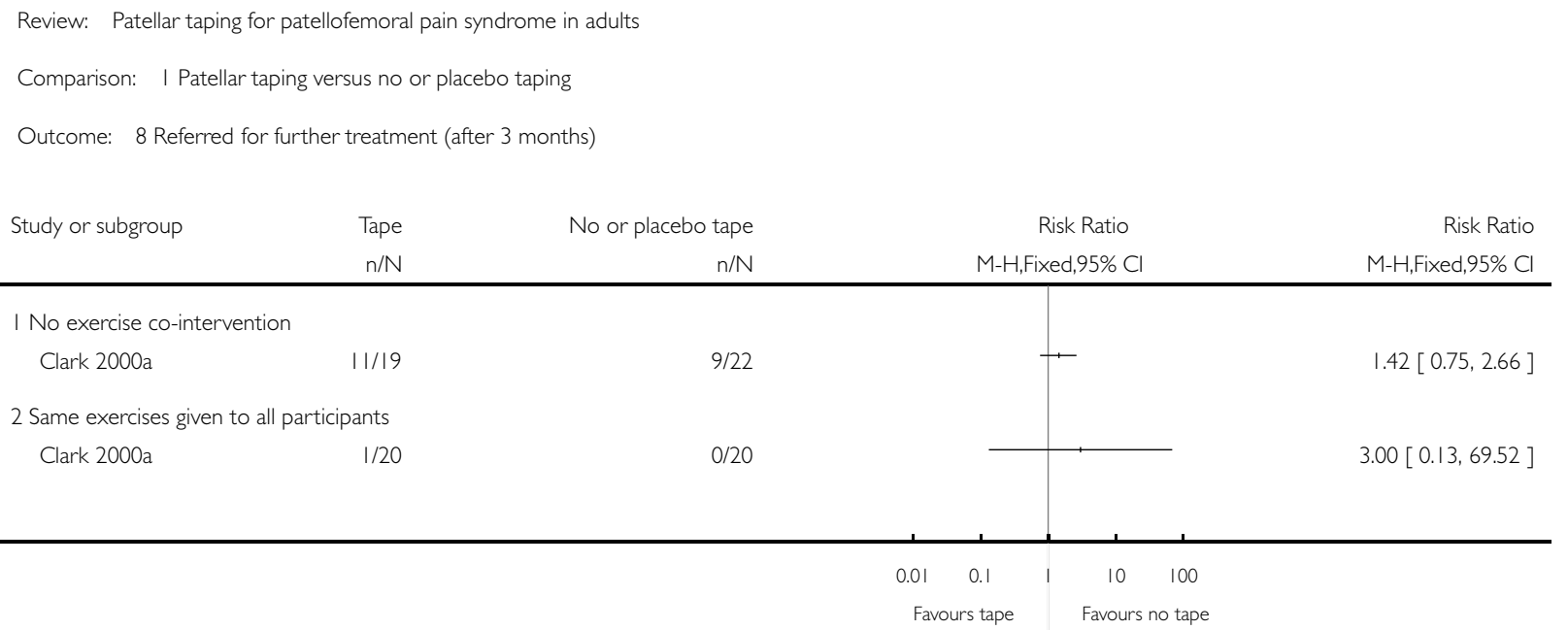

Analysis I.9. Comparison I Patellar taping versus no or placebo taping, Outcome 9 Further course of physiotherapy (after 3 months).

Review: Patellar taping for patellofemoral pain syndrome in adults

Comparison: I Patellar taping versus no or placebo taping

Outcome: 9 Further course of physiotherapy (after 3 months)

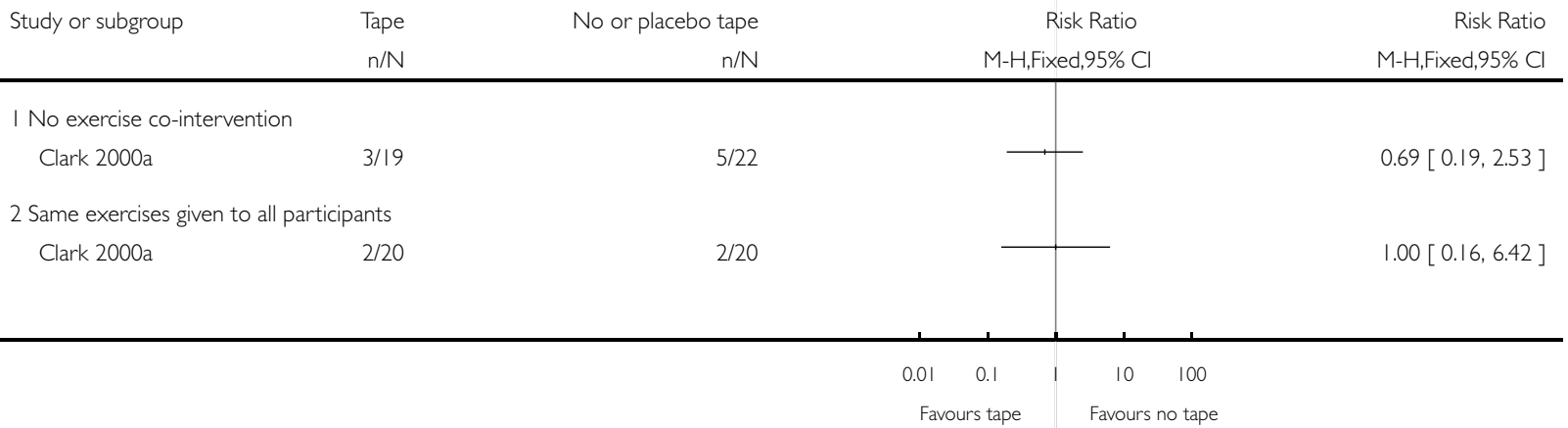




\section{A P P E N D I C E S}

\section{Appendix I. Search strategies}

\section{The Cochrane Library (Wiley InterScience)}

\#1 MeSH descriptor Arthralgia, this term only

\#2 MeSH descriptor Patella, this term only

\#3 (patellofemoral or patello-femoral) NEAR/3 (joint*):ti,ab,kw

\#4 (\#2 OR \#3)

\#5 (\#1 AND \#4)

\#6 (anterior knee pain):ti,ab,kw

\#7 MeSH descriptor Patellofemoral Pain Syndrome, this term only

\#8 (patellofemoral or patello-femoral) ADJ (pain or syndrome or dysfunction):ti,ab,kw

\#9 (lateral compression or lateral facet or lateral pressure or odd facet) ADJ (syndrome):ti,ab,kw

\#10 MeSH descriptor Chondromalacia Patellae, this term only

\#11 (chrondromal ${ }^{*}$ or chondropath*) ADJ (knee or patell* or femoropatell* or femoro-patell* or regropatell* or retro-patell*):ti,ab,kw

\#12 (\#6 OR \#7 OR \#8 OR \#9 OR \#10 OR \#11)

$\# 13$ (taping or tape*):ti,ab,kw

\#14 strap*:ti,ab,kw

\#15 McConnell AND (knee* or patell*):ti,ab,kw

\#16 (\#13 OR \#14 OR \#15)

\#17 (\#5 OR \#12)

\#18 (\#16 AND \#17)

\section{MEDLINE (OVID ONLINE)}

1. Arthralgia/

2. Patella/

3. ((patellofemoral or patello-femoral) adj (joint)).tw

4. 1 and (or/2-3)

5. anterior knee pain.tw

6. Patellofemoral pain syndrome/

7. ((Patello-femoral or patellofemoral) adj (pain or syndrome or dysfunction)).tw

8. ((lateral compression or lateral facet or lateral pressure or odd facet) adj (syndrome)).tw

9. Chondromalacia patellae/

10. ((chondromal\$ or chondropath\$) adj (knee or patell\$ or femoropatell\$ or femoro-patell\$ or retropatell\$ or retro-patell\$)).tw

11. or/5-10

12. (taping or tape $\$$ ).tw

13. strap\$.tw

14. (McConnell and (knee\$ or patell\$)).tw

15. or/ $12-14$

16. (or/4,11) and 15

17. randomized controlled trial.pt

18. controlled clinical trial.pt

19. Randomized Controlled Trials/

20. Random Allocation/

21. Double Blind Method/

22. Single Blind Method/

23. or/17-22

24. Animals/ not Humans/

25. 23 not 24

Patellar taping for patellofemoral pain syndrome in adults (Review)

Copyright $\odot 2012$ The Cochrane Collaboration. Published by John Wiley \& Sons, Ltd. 
26. clinical trial.pt

27. exp Clinical Trials as topic/

28. (clinic $\$$ adj25 trial\$).tw

29. ((singl\$ or doubl\$ or trebl\$ or tripl\$) adj (mask\$ or blind $\$)$ ).tw

30. Placebos/

31. placebo\$.tw

32. random $\$$.tw

33. Research Design/

34. or/26-33

35.34 not 24

36. 35 not 25

37. or $/ 25,36$

38. and $/ 16,37$

\section{EMBASE (OVID ONLINE)}

1. Arthralgia/

2. Patella/

3. Patellofemoral joint/

4. 1 and (or/2,3)

5. anterior knee pain.tw

6. Patellofemoral pain syndrome/

7. ((patello-femoral or patellofemoral) adj (pain or syndrome or dysfunction)).tw

8. ((lateral compression or lateral facet or lateral pressure or odd facet) adj (syndrome)).tw

9. Patella chondromalacia/

10. ((chondromal\$ or chondropath\$) adj (knee or patell\$ or femoropatell\$ or femoro-patell\$ or retropatell\$ or retro-patell\$)).tw

11. or $/ 5-10$

12. (taping $\$$ or tape $\$$ ).tw

13. strap\$.tw

14. (McConnell and (knee or patell\$)).tw

15. or/12-14

16. (or/4,11) and 15

17. Clinical trial/

18. Randomized Controlled trial/

19. Randomisation/

20. Double Blind Procedure/

21. Single Blind Procedure/

22. Crossover Procedure/

23. Placebo/

24. randomi? ed controlled trial\$.tw

25. RCT.tw

26. random allocation.tw

27. randomly allocated.tw

28. allocated randomly.tw

29. (allocated adj2 random).tw

30. single blind $\$$.tw

31. double blind \$.tw

32. ((triple or treble) adj (blind $\$)$ ).tw

33. placebo\$.tw

34. Prospective study/

35. or/17-34

36. Case study/

37. case report.tw

Patellar taping for patellofemoral pain syndrome in adults (Review)

Copyright $\odot 2012$ The Cochrane Collaboration. Published by John Wiley \& Sons, Ltd. 
38. Abstract report/ or Letter/

39. or $/ 36-38$

40.35 not 39

41. limit 40 to human

42. and/16,41

\section{CINAHL (EBSCO)}

1. Arthralgia/

2. Patella/

3. ((patellofemoral or patello-femoral) adj (joint)).tw

4. 1 and (or/2,3)

5. anterior knee pain.tw

6. Patellofemoral pain syndrome/

7. ((patello-femoral or patellofemoral) adj (pain or syndrome or dysfunction)).tw

8. ((lateral compression or lateral facet or lateral pressure or odd facet) adj (syndrome)).tw

9. Chondromalacia patella/

10. ((chondromal\$ or chondropath\$) adj (knee or patell\$ or femoro $\$$ or femoro-patell\$ or retropatell $\$$ or retro-patell $\$)$ ).tw

11. or $/ 5-10$

12. "Taping and strapping"/

13. (taping or tape $\$$ ).tw

14. strap\$.tw

15. (McConnell and (knee\$ or patell\$)).tw

16. or/12-15

17. (or/4,11) and 16

18. exp Clinical Trials/

19. exp Evaluation Research/

20. exp Comparative Studies/

21. exp Crossover Design/

22. clinical trial.pt

23. or/18-22

24. ((clinical or controlled or comparative or placebo or prospective or randomi\#ed) adj3 (trial or study)).tw

25. (random $\$$ adj7 (allocat $\$$ or allot $\$$ or assign $\$$ or basis $\$$ or divid $\$$ or order $\$)$ ).tw

26. ((singl\$ or doubl\$ or trebl\$ or tripl\$) adj7 (blind $\$$ or mask $\$))$.tw

27. (cross?over\$ or (cross adj1 over\$)).tw

28. ( (allocat $\$$ or allot $\$$ or assign $\$$ or divid $\$$ ) adj3 (condition $\$$ or experiment $\$$ or intervention $\$$ or treatment $\$$ or therap $\$$ or control\$ or group\$)).tw

29. or/ $24-28$

30. or/23,29

31. and $/ 17,30$

\section{PEDro}

Abstract \& Title: (tape* or taping)

Therapy: no selection

Problem: no selection

Body part: lower leg or knee

Subdiscipline: no selection

Method: clinical trial

Match all search terms (AND)

Patellar taping for patellofemoral pain syndrome in adults (Review) 


\section{SPORTDiscus (EBSCO)}

1. Kneel

2. Knee joint/

3. Patella/

4. Patellofemoral joint/

5. or/ $1-4$

6. anterior knee pain.tw

7. Patellofemoral pain syndrome/

8. ((patello-femoral or patellofemoral) adj (pain or syndrome or dysfunction)).tw

9. ((lateral compression or lateral facet or lateral pressure or odd facet) adj (syndrome)).tw

10. Chondromalacia/

11. (chondromal\$ or chondropath\$) adj (knee or patell\$ or femoropatell\$ or femoro-patell\$ or retropatell\$ or retro-patell\$).tw

12. or/ 6-11

13. (tape $\$$ or taping).tw

14. strap\$.tw

15. (McConnell and (knee\$ or patell\$)).tw

16. or/13-15

17. (or/ 5,12$)$ and 16

18. ((clinic $\$$ or controlled or comparative or placebo or prospective or randomi\#ed) adj3 (trial or study)).tw

19. (random $\$$ adj7 (allocat $\$$ or allot $\$$ or assign $\$$ or basis $\$$ or divid $\$$ or order $\$)$ ).tw

20. ((singl\$ or doubl\$ or trebl\$ or tripl\$) adj7 (blind $\$$ or mask $\$)$ ).tw

21. (cross?over\$ or (cross adj1 over\$)).tw

22. randomi?ed control\$ trial\$.tw

23. ( $($ allocat $\$$ or allot $\$$ or assign $\$$ or divid $\$$ ) adj3 (condition $\$$ or experiment $\$$ or intervention $\$$ or treatment $\$$ or therap $\$$ or control $\$$ or group\$)).tw

24. placebo\$.tw

25. or/18-24

30. and $/ 17,25$

\section{AMED (OVID ONLINE)}

1. Arthralgia/

2. Patella/

3. ((patellofemoral or patello-femoral) adj (joint)).tw

4. 1 and (or/2,3)

5. anterior knee pain.tw

6. Patellofemoral pain/

7. ((patello-femoral or patellofemoral) adj (pain or syndrome or dysfunction)).tw

8. ((lateral compression or lateral facet or lateral pressure or odd facet) adj (syndrome)).tw

9. ((chondromal\$ or chondropath\$) adj (knee or patell $\$$ or femoro $\$$ or femoro-patell $\$$ or retropatell $\$$ or retro-patell $\$)$ ).tw

10. or/ 5-9

11. (taping or tape $\$$ ).tw

12. strap\$.tw

13. ((McConnell) and (knee\$ or patell\$)).tw

14. or/11-13

15. (or/4,10) and 14

16. randomized controlled trial.pt

17. controlled clinical trial.pt

18. Randomized Controlled Trials/

19. Random Allocation/

20. Double-Blind Method/

21. or/ $16-20$

22. Animals/ not Humans/

Patellar taping for patellofemoral pain syndrome in adults (Review)

Copyright $\odot 2012$ The Cochrane Collaboration. Published by John Wiley \& Sons, Ltd. 
23. 21 not 22

24. clinical trial.pt

25. exp Clinical Trials/

26. (clinic $\$$ adj25 trial\$).tw

27. ((singl\$ or doubl $\$$ or trebl $\$$ or tripl $\$$ ) adj (mask $\$$ or blind $\$)$ ).tw

28. Placebos/

29. placebo\$.tw

30. random $\$$.tw

31. Research Design/

32. (latin adj square).tw

33. or/24-32

34. 33 not 22

35.34 not 23

36. and $/ 15,23$

37. and $/ 15,35$

38. or/ 36,37

\section{H I S T O R Y}

Protocol first published: Issue 3, 2007

Review first published: Issue 4, 2012

\begin{tabular}{l|l|l}
\hline Date & Event & Description \\
\hline 11 September 2008 & Amended & Converted to new review format. \\
\hline
\end{tabular}

\section{CONTRIBUTIONSOFAUTHORS}

Michael Callaghan and James Selfe conceived the idea and wrote the protocol. They performed the search, performed study selection, reviewed the included studies and drafted the review. Michael Callaghan is the guarantor of the review.

\section{DECLARATIONSOF INTEREST}

None known.

\section{SOURCES OF SUPPORT}




\section{Internal sources}

- University of Manchester, UK.

- University of Central Lancashire, UK.

\section{External sources}

- Department of Health Post Doctoral Award, UK.

- Arthritis Research, UK.

\section{DIFFERENCES BETWEEN PROTOCOLANDREVIEW}

We clarified that our intention was to compare tape versus no or placebo tape and thus we excluded studies that compared patellar taping with another intervention (such as exercises) or that compared composite interventions, that included patellar taping, with no intervention or different interventions.

In the protocol under the title 'Timepoints considered', we stated that we would consider studies that analysed the effect of patellar taping immediately post application. We have removed this and have only considered patellar taping when it was used as part of a treatment programme for a sustained period. We have also removed 'change of range of motion' as one of the 'Types of outcome measures'.

In accordance with the latest Cochrane recommendations, we have completely replaced the quality assessment tool with the 'Risk of bias' tool.

\section{NDEX TERMS}

\section{Medical Subject Headings (MeSH)}

*Bandages; *Surgical Tape; Pain Measurement [methods]; Patellofemoral Pain Syndrome [*therapy]; Randomized Controlled Trials as Topic; Treatment Outcome

\section{MeSH check words}

Adult; Humans 